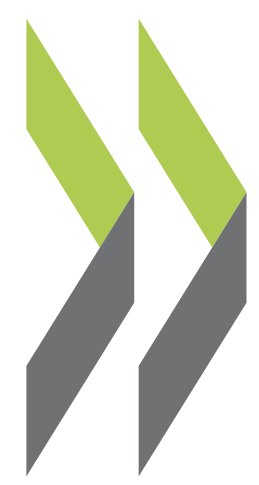

OECD Economics Department Working Papers No. 1153

Reducing Income Inequality and Poverty and Promoting Social Mobility in Korea

Randall S. Jones, Satoshi Urasawa 
Organisation de Coopération et de Développement Économiques

Organisation for Economic Co-operation and Development

24-Jul-2014

ECONOMICS DEPARTMENT

English - Or. English

REDUCING INCOME INEQUALITY AND POVERTY AND

PROMOTING SOCIAL MOBILITY IN KOREA

ECONOMICS DEPARTMENT WORKING PAPERS No. 1153

By Randall S. Jones and Satoshi Urasawa

OECD Working Papers should not be reported as representing the official views of the OECD or its member countries. The opinions expressed and arguments employed are those of the author(s).

Authorised for publication by Robert Ford, Deputy Director, Country Studies Branch, Economics Department.

All OECD Economics Department Working Papers are available through OECD's Internet website at www.oecd.org/eco/workingpapers

\section{JT03360681}

Complete document available on OLIS in its original format

This document and any map included herein are without prejudice to the status of or sovereignty over any territory, to the delimitation of international frontiers and boundaries and to the name of any territory, city or area. 
OECD Working Papers should not be reported as representing the official views of the OECD or of its member countries. The opinions expressed and arguments employed are those of the author(s).

Working Papers describe preliminary results or research in progress by the author(s) and are published to stimulate discussion on a broad range of issues on which the OECD works.

Comments on Working Papers are welcomed, and may be sent to the Economics Department, OECD, 2 rue André-Pascal, 75775 Paris Cedex 16, France, or by e-mail to eco.contact@,oecd.org.

This document and any map included herein are without prejudice to the status of or sovereignty over any territory, to the delimitation of international frontiers and boundaries and to the name of any territory, city or area.

The statistical data for Israel are supplied by and under the responsibility of the relevant Israeli authorities. The use of such data by the OECD is without prejudice to the status of the Golan Heights, East Jerusalem and Israeli settlements in the West Bank under the terms of international law.

(C) OECD (2014)

You can copy, download or print OECD content for your own use, and you can include excerpts from OECD publications, databases and multimedia products in your own documents, presentations, blogs, websites and teaching materials, provided that suitable acknowledgment of OECD as source and copyright owner is given. All requests for commercial use and translation rights should be submitted to rights@oecd.org 
ECO/WKP(2014)49

\section{ABSTRACT/RÉSUMÉ \\ Reducing Income Inequality and Poverty and Promoting Social Mobility in Korea}

To strengthen social cohesion, a top government priority, it is essential to address the labour market roots of inequality by breaking down dualism to reduce the share of non-regular workers and to boost the employment ratio toward the government's $70 \%$ target. Education reforms are also important to enhance social mobility. Social welfare programmes should be improved to make them more effective, especially among the elderly, where the relative poverty rate is $49 \%$. In addition, reforms are needed now to develop an effective three-pillar system of retirement income based on the National Pension Scheme, company pensions and individual savings. High household debt also has adverse implications for equity, as well as for growth, as individuals with low income and credit ratings have limited access to financial markets and many are delinquent on their loans. Policies to offer credit to such households and restructure their debt, while limiting moral hazard and developing market-based lending, are essential.

This Working Paper relates to the 2014 OECD Economic Survey of Korea (www.oecd.org/eco/economicsurvey-korea.htm).

JEL Classification: H55, J26

Keywords: labour market dualism, non-regular workers, 70\% roadmap, female employment, elderly poverty, National Pension Scheme, Basic Livelihood Security Programme, basic old-age pension, company pensions, retirement allowance, hagwons, household debt, National Happiness Fund

$* * * * * * * * * * * * * * * * * * * * * * * * *$

\section{Réduire les inégalités de revenu et la pauvreté et promouvoir la mobilité sociale en Corée}

Pour renforcer la cohésion sociale, l'une des premières priorités des autorités coréennes, il est primordial de s'attaquer au dualisme du marché du travail, source d'inégalités, en réduisant la proportion de travailleurs non réguliers et en favorisant le rapprochement du taux d'emploi sur l'objectif de $70 \%$ fixé par les autorités. Des réformes de l'éducation sont également essentielles pour une plus grande mobilité sociale. Les programmes de protection sociale doivent être améliorés pour qu'ils soient plus efficaces, notamment pour les personnes âgées, dont le taux de pauvreté relative est de $49 \%$. En outre, des réformes sont nécessaires pour mettre en place un régime de retraite à trois piliers : régime national de retraite, retraites d'entreprise et épargne individuelle. Par ailleurs, le haut niveau d'endettement des ménages a des effets négatifs en termes d'égalité car les ménages les plus modestes et les moins solvables n'ont guère accès au marché du crédit et leurs taux de défaillance sont élevés. Il est important d'élaborer une offre de crédit en leur faveur et de réaménager leur dette, tout en limitant l'aléa moral et en développant le recours aux mécanismes du marché dans l'activité de prêt.

Ce Document de travail se rapporte à l'Étude économique de l'OCDE de la Corée, 2014 (www.oecd.org/fr/eco/coree.htm).

Classification JEL : H55, J26

Mots clés : dualisme du marché du travail, travailleurs non réguliers, emploi des femmes, pauvreté chez les plus âgés, régime national de retraite, programme de garantie du minimum de subsistance, minimum vieillesse, retraites d'entreprise, indemnité de retraite, hagwons, endettement des ménages 


\section{TABLE OF CONTENTS}

\section{REDUCING INCOME INEQUALITY AND POVERTY AND PROMOTING SOCIAL MOBILITY IN

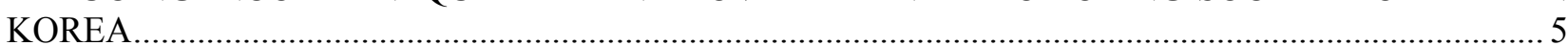

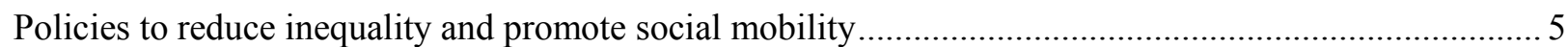

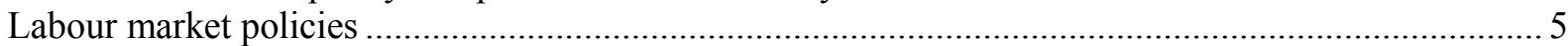

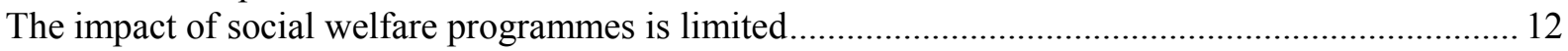

Enhancing the contribution of education to social cohesion ............................................................ 14

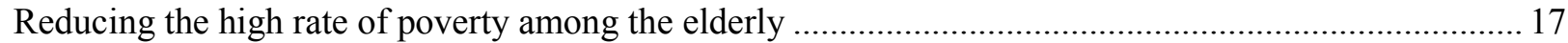

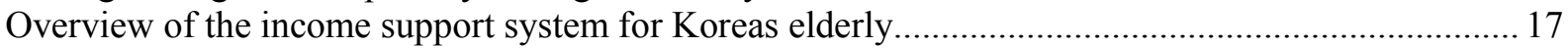

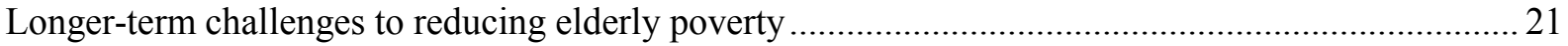

Addressing elderly poverty, while ensuring the long-run sustainability of the NPS ........................... 22

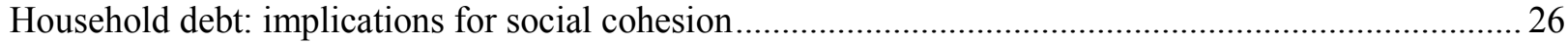

The governments response to high and rising household debt ...........................................................26

The results of policies to address the social dimensions of household debt ......................................... 30

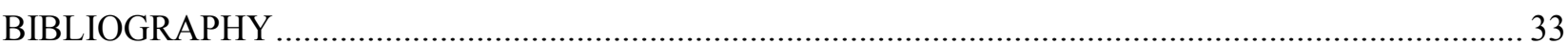

\section{Tables}

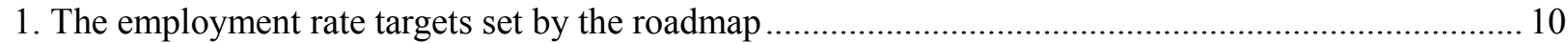

2. Long-term projections of the coverage of the National Pension Scheme ........................................... 20

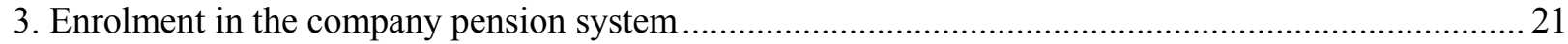

4. Long-term projections of the National Pension Scheme's financial balance....................................... 22

5. The share of household lending by type of financial institution varies based on credit ratings............ 28

6. Interest rates on loans to households vary widely by type of lender ...................................................29

7. Preferential loans to people with low income and poor credit ratings ................................................ 30

\section{Figures}

1. Income inequality and relative poverty in Korea are above the OECD average ................................... 6

2. Skills of temporary workers in Korea match those of permanent workers ........................................ 7

3. The probability of workers making the transition from fixed-term to regular status is low .................. 9

4. Responses of women in the labour force to marriage and childbirth ................................................. 11

5. Income levels provided by cash minimum-income benefits ........................................................ 13

6. The percentage of students attending after-school lessons in Korea is exceptionally high................... 15

7. Household income is closely linked with outlays and participation in private tutoring....................... 16

8. Koreas elderly income support system has multiple pillars .............................................................. 18

9. Basic, non-contributory pensions in OECD countries ................................................................. 19

10. Population ageing in Korea is projected to be the fastest in the OECD area ................................... 21

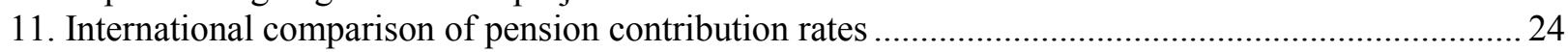

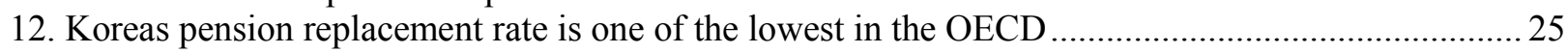

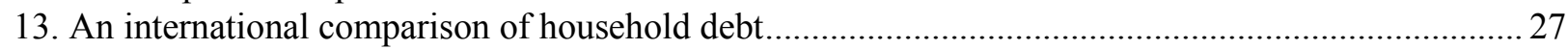

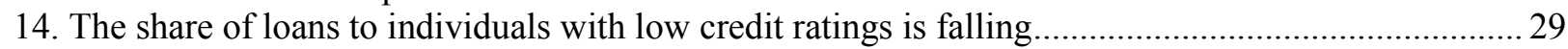

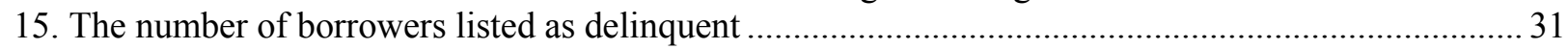

\section{Boxes}

Box 1. Summary of recommendations to promote social cohesion in Korea ........................................ 32 


\title{
REDUCING INCOME INEQUALITY AND POVERTY AND PROMOTING SOCIAL MOBILITY IN KOREA
}

\author{
By Randall S. Jones and Satoshi Urasawal
}

Korea is well known for achieving rapid economic development and social cohesion. From 1980 until the 1997 crisis, the Gini coefficient measure of income inequality declined. Since that crisis, however, inequality has risen significantly, reflecting increased labour market dualism leading to a high degree of wage inequality. By 2009, the ratio of the top to the bottom quintile had risen to 5.7, while the relative poverty rate, at $15 \%$, was the eighth highest in the OECD area (Figure 1). Rising inequality has squeezed the middle class: the share of the population with an income between $50 \%$ and $150 \%$ of the national median fell from $75 \%$ in 1990 to $68 \%$ in 2010 . Inequality is a pressing problem, not least as it reduces social mobility over generations. Other well-being indicators, such as work-life balance and health status, also point to tensions in Korean society.

In contrast to many other OECD countries, the latest indicators suggest that income inequality has declined, if only slightly, in Korea since the 2008 crisis, while the relative poverty rate has remained fairly stable. Nevertheless, social cohesion remains at the top of the government's policy agenda. Indeed, the administration that took office in 2013 pledged to boost public social spending over the period 2013-17. This paper begins by addressing a number of issues that are key to social cohesion: $i$ ) the labour market challenges of dualism and boosting the employment rate to $70 \%$; ii) the limited impact of social welfare programmes; and iii) the role of education, including private tutoring. The following sections address the high poverty rate among the elderly and the implications of high household debt for social cohesion. Policy recommendations are summarised at the end of the paper.

\section{Policies to reduce inequality and promote social mobility}

\section{Labour market policies}

\section{Breaking down labour market dualism}

Dualism in Korea is exceptionally strong. Non-regular workers, such as fixed-term, part-time and dispatched workers, have accounted for around a third of dependent employment during the past decade. The share of temporary workers (24\%), who account for a majority of non-regular workers in Korea, was the fourth highest in the OECD area in 2012 and more than double the OECD average. Dualism is a major source of inequality, as non-regular workers were paid $64 \%$ as much as regular workers in 2012 . The large gap is inconsistent with the level of skills of non-regular workers. According to the OECD study on the skills of adults, the literacy skills of temporary workers in Korea was equivalent to those of permanent prime-age workers (25 to 54) and even higher in the 16-to-24 age group (Figure 2). However, they are penalised by their relatively short tenure, given the strong link between tenure and wages in Korea. Indeed,

1. Randall S. Jones is head of the Japan/Korea Desk in the Economics Department of the OECD and Satoshi Urasawa is an economist on that Desk. This paper was originally produced for the OECD Economic Survey of Korea published in June 2014 under the authority of the Economic and Development Review Committee (EDRC). The author would like to thank Andrew Dean, Robert Ford, Michael Förster, Myungkyoo Kim, Vincent Koen, and Andrew Reilly, as well as officials from the Korean government, for valuable comments on earlier drafts. Special thanks go to Lutécia Daniel for technical assistance and to Nadine Dufour and Mikel Inarritu for technical preparation. 
the average tenure of non-regular workers in 2012 was only 28 months, compared to 82 for regular workers. Even after adjusting for tenure, as well as other characteristics such as gender, age, place of employment and educational attainment, the wage gap remained sizeable at $8.4 \%$ in 2012 , suggesting that discrimination still plays a role. The wage disparity rises as the size of firms increases (MOEL, 2012).

Figure 1. Income inequality and relative poverty in Korea are above the OECD average

In 2010 or latest year available
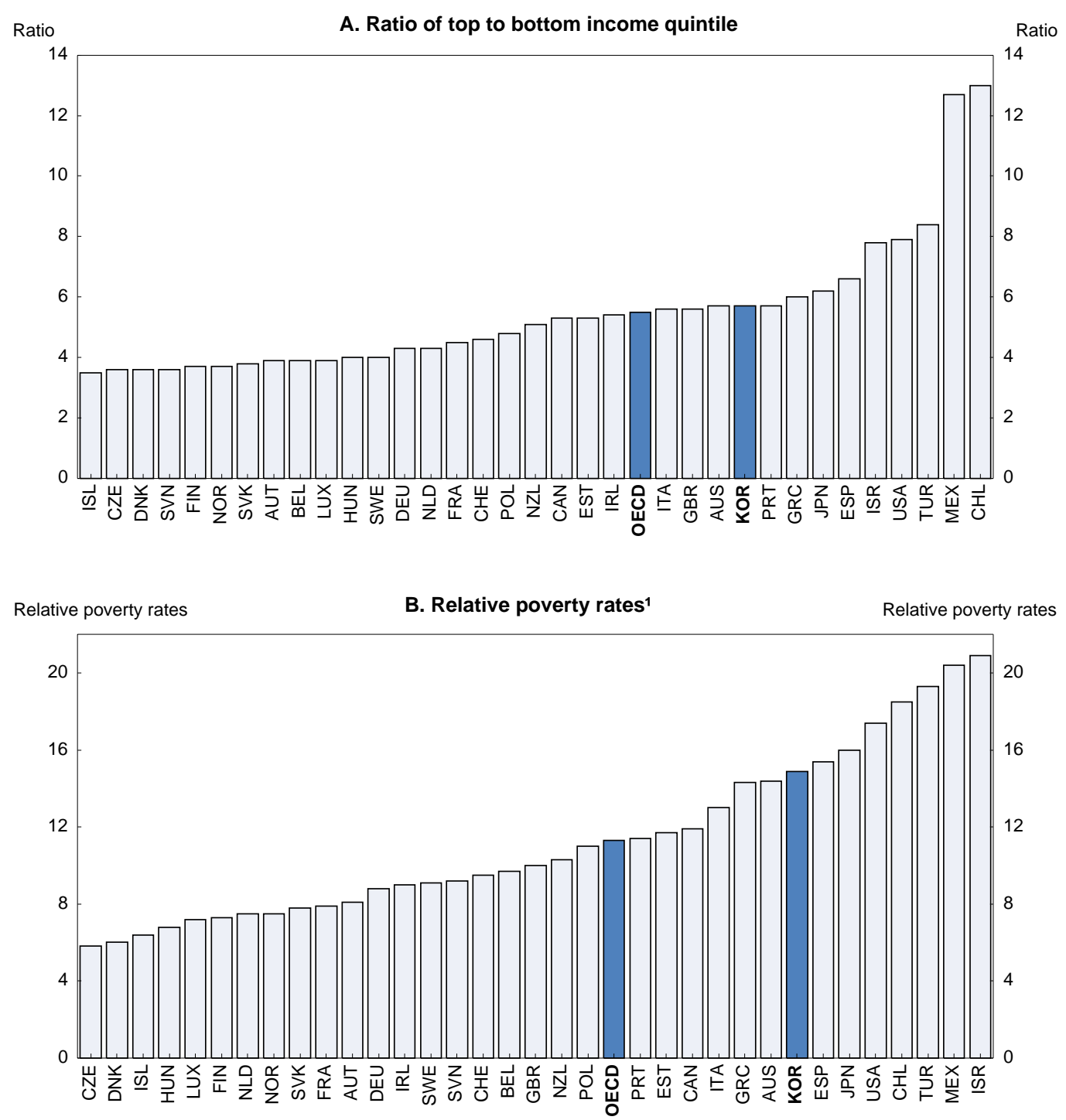

1. The poverty threshold is set at $50 \%$ of the median for the entire population.

Source: OECD Database on Income Distribution and Poverty. 
Figure 2. Skills of temporary workers in Korea match those of permanent workers

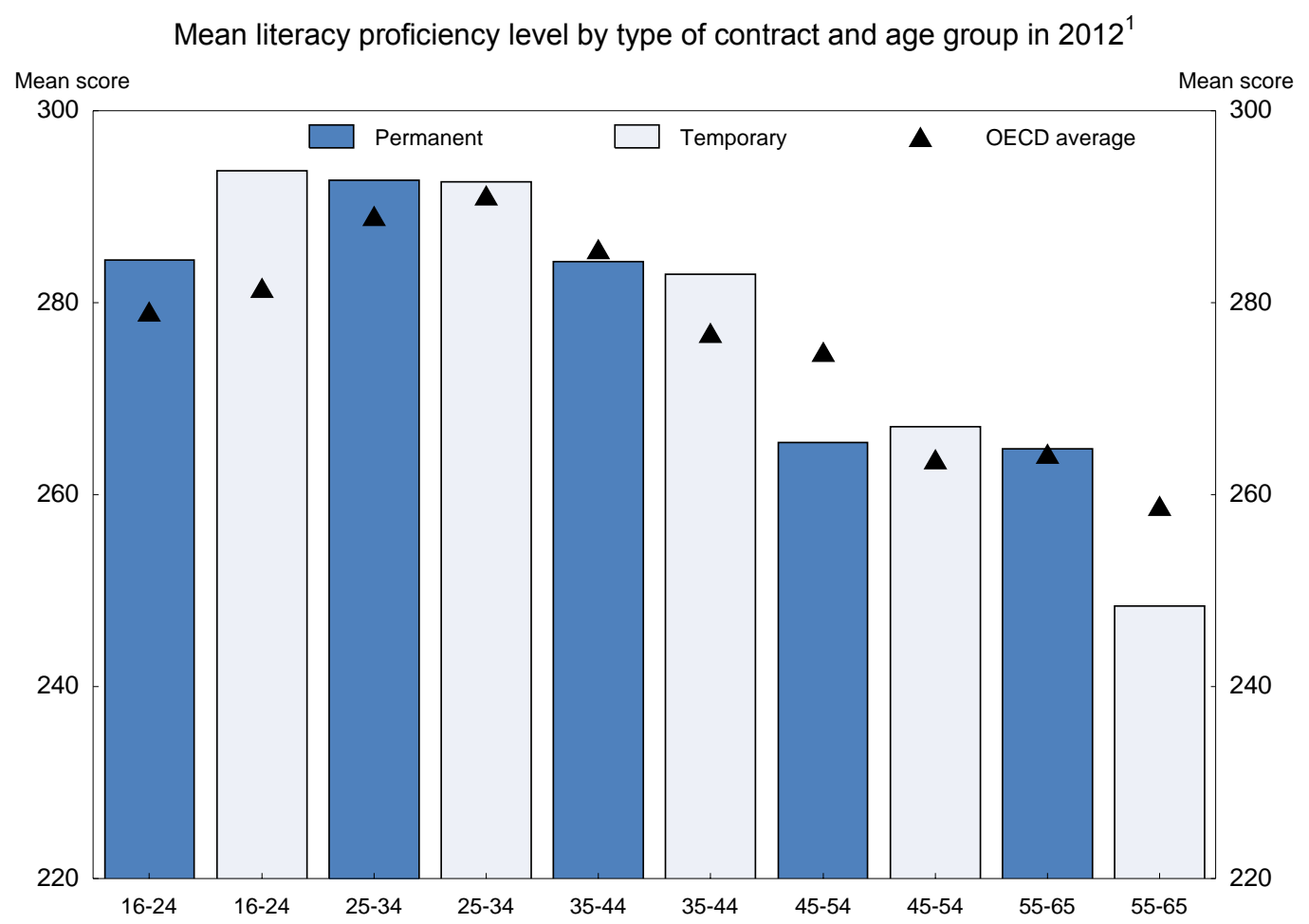

1 The results for numeracy skills are similar to those for literacy, while the third category - problem-solving - shows smaller gaps by age group and type of contract.

Source: OECD (2013d).

Labour market dualism is thus a key factor in income inequality. Almost a quarter of full-time workers in Korea earn less than two-thirds of the median wage, the highest share in the OECD. Moreover, overall earnings dispersion for full-time workers, measured by the ratio of the $9^{\text {th }}$ decile to the $1^{\text {st }}$, was the third highest. Dualism has a number of other negative implications for social cohesion:

- Less coverage by the social safety net: Although the legal framework requires nearly all privatesector workers to be covered by the social insurance system, coverage is low for non-regular workers, despite the introduction of government subsidies to help pay premiums. In 2012, only $43 \%$ of non-regular workers, who have precarious jobs, were covered by employment insurance. Also, only $39 \%$ of non-regular workers were covered in their workplace by the National Pension Scheme and $45 \%$ by the National Health Insurance.

- Precarious employment: Shorter tenure causes job instability. Indeed, the worker turnover rate ${ }^{2}$ was $67 \%$ in 2012, twice the OECD average (OECD, 2013c).

- Less access to training: Shorter tenure reduces the incentive for firms to invest in training nonregular workers. Indeed, the share of non-regular workers in training is smaller than that of regular workers in all age groups, thus slowing human capital accumulation (OECD, 2013c).

2. The turnover rate is the sum of hirings (estimated by the number of workers in a given year with less than one year of tenure) and separations (estimated as the difference between hirings and net employment change), divided by total employment. 
- Gender inequality: Women's share of non-regular employment (53\%) is much higher than their share of total dependent employment (43\%), contributing to the large gender wage gap.

The limited mobility between regular and non-regular employment exacerbates the negative equity consequences of dualism. Non-regular employment is not a pathway to regular employment in Korea. The probability of moving from temporary (defined as fixed term and dispatched workers) to permanent employment over a one-year period was only $11.1 \%$ in Korea, compared to more than $50 \%$ in a number of European countries (OECD, 2013c). However, there is more mobility in the other direction; over a ten-year period, $70 \%$ of workers who shifted from non-regular to regular status lost their regular status within four years, suggesting that even those who move to regular status do not enjoy a stable situation (Kim and Lee, 2013).

Labour market dualism thus creates serious equity problems as a significant share of employees work in precarious jobs at relatively low wages and with less protection from social insurance. Firms hire nonregular workers to reduce labour costs and to achieve greater employment flexibility, given the difficulty and cost of laying off regular workers, who receive relatively high employment protection as a result of government policies, business practices, social customs and labour unions (Koh et al., 2010). International evidence suggests that the creation of temporary jobs is a common response of firms to high costs of reducing permanent jobs (Kahn, 2010). According to a 2012 government survey, more than half of nonregular workers are involuntarily employed as non-regular workers, indicating that dualism is driven primarily by firms' preferences. Dualism thus acts as a restraint on employment. Indeed, the government aims to achieve a $70 \%$ employment rate (see below) in part by creating "high-quality" part-time jobs.

Various measures have been taken to address labour market dualism. In particular, the 2007 labour law limited non-regular workers' employment to a maximum of two years, with some exceptions, while supporting their transition to regular status. However, according to government statistics for 2010-13 on fixed-term workers who have worked 18 months or more and whose employment contract had expired, around one-half leave their firm when their contract ends (Figure 3). The proportion is $66 \%$ at firms with more than 300 employees. Meanwhile, less than one-third of workers are converted to regular status as intended. In short, the 2007 reform appears to have increased job precariousness, compared to the past when many fixed-term workers had their contracts rolled over. In addition, there has been a diversification in the types of non-regular workers. The 2007 labour law also prohibited "unreasonable discrimination", in terms of wages and working conditions, between non-regular and regular workers who work in the same or similar jobs in the same firm. However, only 2529 cases were filed over 2007-12.

In 2011, the government launched the "Comprehensive Non-regular Workers Initiative" to address dualism by: i) introducing subsidies for small and medium-sized enterprises' (SMEs) contributions to social insurance systems to expand the coverage of their employees, including non-regular workers; ii) broadening the coverage of social insurance to include special types of employment, such as delivery vehicle drivers; iii) improving enforcement of the minimum wage law; iv) expanding vocational training opportunities for non-regular workers; and v) reducing discrimination against non-regular workers. In addition, the government announced a plan in 2013 to convert around $26 \%$ of fixed-term workers in the public sector to regular status by 2015 . However, the impact is limited by the fact that the public sector accounts for only $6 \%$ of non-regular workers. Private firms are encouraged, in part through tax incentives, to grant regular status to their non-regular workers.

The government has addressed dualism primarily by limiting the use of non-regular workers, as well as by strengthening the social safety net and encouraging equal treatment for non-regular workers. Better coverage by the safety net and reduced discrimination would improve conditions for non-regular workers and help achieve the goal of boosting the employment ratio to $70 \%$. However, the regulations restricting the use of non-regular workers may tend to increase the cost of employment flexibility and lower overall 
employment, without addressing the fundamental causes of dualism. Breaking down dualism requires a comprehensive strategy to reduce the factors that encourage firms to hire non-regular workers, notably by relaxing effective employment protection for regular workers and increasing social insurance coverage to narrow the wage gap, while upgrading training programmes for non-regular workers. In addition, given that $70 \%$ of non-regular workers are in firms with less than 30 workers, where productivity tends to be low, Measures to reduce dualism should be co-ordinated with SME policies (2014 OECD Economic Survey of Korea).

Figure 3. The probability of workers making the transition from fixed-term to regular status is low

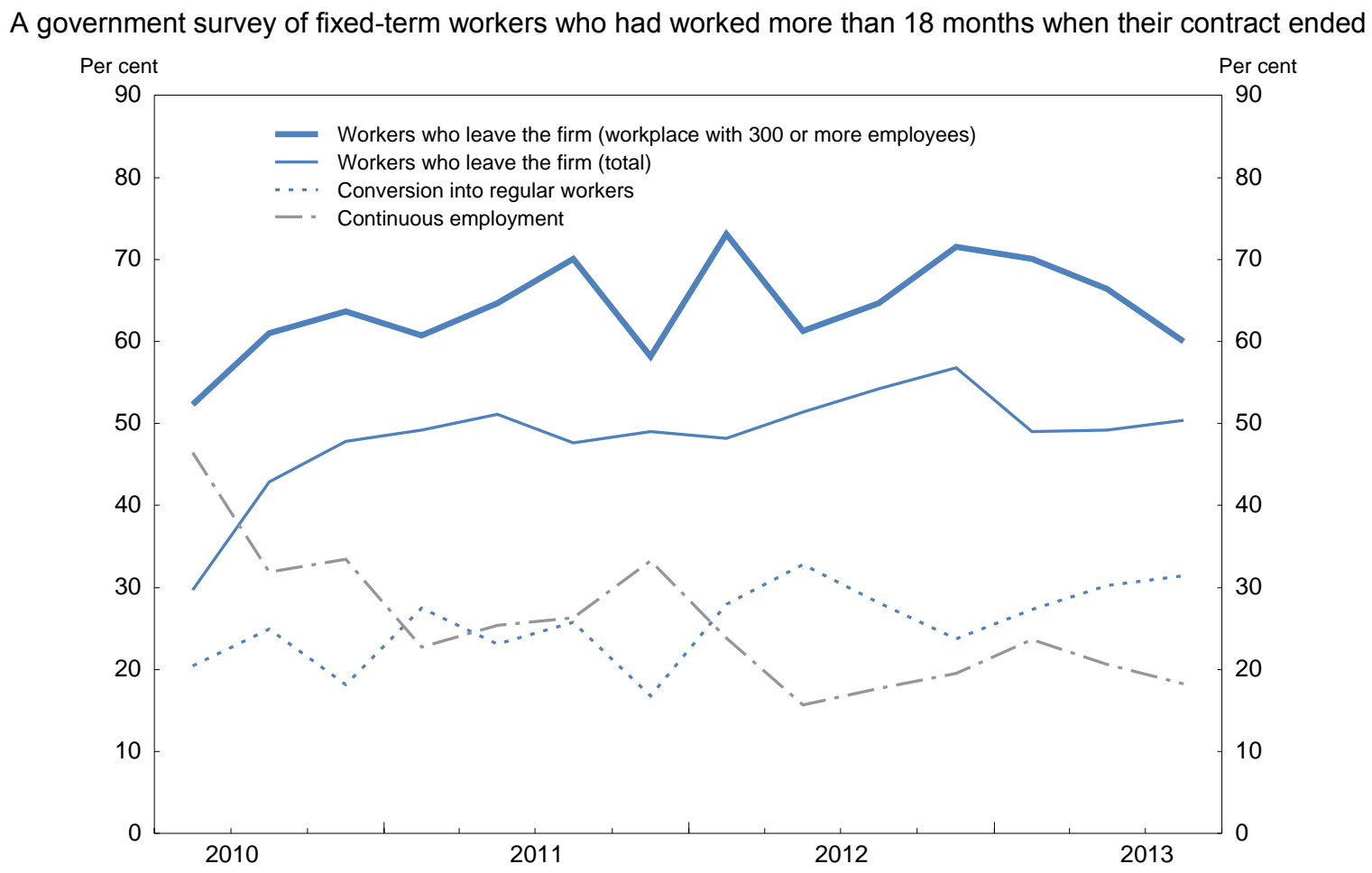

Source: Ministry of Employment and Labour.

The roadmap to boost the employment rate to $70 \%$

In June 2013, Korea announced a roadmap to boost employment to $70 \%$ of the working-age population by 2017 (Table 1). This target was reinforced in the January 2014 "4-7-4 vision" of a 4\% growth rate, $70 \%$ employment rate, and a per capita income of $\$ 40$ thousand (from $\$ 26$ thousand in 2013). Korea's employment rate, which has been steady at around 64\% since 2003, edged up from $64.2 \%$ in 2012 to $64.6 \%$ in 2013 and the roadmap targets a $65.6 \%$ rate in 2014 . Employment is to be increased by fostering a "creative economy" (2014 OECD Economic Survey of Korea) and by changing the way of working by reducing working hours, encouraging flexible work schedules and boosting the number of parttime jobs from 1.5 million in 2012 to 2.4 million in 2017, in part by creating such jobs in the government. Although working hours have been declining, they are still one-fifth more than above the OECD average of 1769 hours per year.

Boosting employment to $70 \%$ - a level achieved by 13 OECD countries - would provide numerous social and economic benefits. Breaking down barriers to women in employment and entrepreneurship would enhance equity and help mitigate the impact of rapid population ageing. Moreover, job creation that 
is accompanied by a decline in working hours, as planned in the roadmap, would create more familyfriendly workplaces, thus enhancing the well-being of society. About $85 \%$ of men and $75 \%$ of women in Korea work more than 40 hours per week, with adverse implications for the quality of life, as well as the fertility rate, which is the lowest in the OECD area (Yamaguchi and Youm, 2012).

Table 1. The employment rate targets set by the roadmap

As a per cent of the working-age population

\begin{tabular}{lcc}
\hline & $\mathbf{2 0 1 2}$ & $\mathbf{2 0 1 7}$ \\
\cline { 2 - 3 } Total & 64.2 & 70.0 \\
Women & 53.5 & 61.9 \\
Men & 74.9 & 78.1 \\
Youth (15 to 29) & 40.4 & 47.7 \\
Adults (30 to 54) & 75.6 & 81.0 \\
Older persons (55 to 64) & 63.1 & 67.8 \\
\hline
\end{tabular}

Source: Government of Korea.

However, the roadmap will be difficult to achieve, given the reluctance of regular workers to accept more leisure in exchange for less pay. In addition, part-time jobs are treated as non-regular work, as noted above, with much lower hourly pay and benefits. Firms prefer to meet increased demand by lengthening working time rather than by expanding the number of workers, given the fixed costs of hiring and the employment protection that makes it expensive to dismiss unnecessary workers. Overcoming these obstacles requires an agreement among the social partners.

The 70\% target includes large increases in the employment rates of women, youth and older persons. The female participation rate was $53.5 \%$ of the working-age population in 2012 , well below the OECD average of $62 \%$. If participation rates were to remain at their current levels for each age group and gender, the total labour force would peak at 27.2 million in 2022 and then fall to 21.5 million by 2050 . However, if the female participation rate were to reach the current level for males for each age group by 2050 , the labour force in that year would be nearly 25.6 million.

The low female participation rate reflects the withdrawal of most women from the labour force at the time of marriage or childbirth, although most eventually return, resulting in an M-shaped pattern across their lifetime. In 2007, 58\% of women in the labour force withdrew when they marry, with the figure much higher for employees than for the self-employed or family workers (Figure 4). Another 27\% leave at the time of the birth of their first child and $10 \%$ when a second child is born. Women with higher educational attainment were less likely to withdraw following marriage than those with less educational attainment, but more likely to withdraw following the birth of a child than women with a high school education or less (Panel B). Of Korea's 9.7 million married women between the ages of 15 and 54 in 2013, 4.1 million were not in the labour force. Of those women, about half - nearly 2 million - were "career-break" women who left jobs due to family responsibilities; $45.9 \%$ cited marriage as the reason for leaving the labour force, followed by childcare (29.2\%), pregnancy and childbirth $(21.2 \%)$ and their children's education (3.7\%) (Statistics Korea, 2013).

Following maternity leave, parents can have one year of parental leave or reduced working hours. Under the roadmap, the government has proposed that parents be allowed to choose up to two years of reduced work hours instead of one year of parental leave. Such measures will help parents combine work with family responsibilities. However, lengthy childcare leave and shortened working time, combined with increased part-time employment, might drive women to the periphery in workplaces and leave them more focused on already heavy family responsibilities. The withdrawal of women from employment reflects the challenge of combining jobs with family responsibilities. In the OECD area, women spend two hours more 
per day on average than men on unpaid household work, but in Korea the gap is three hours. Greater gender equity in unpaid work would facilitate female employment.

Figure 4. Responses of women in the labour force to marriage and childbirth ${ }^{1}$
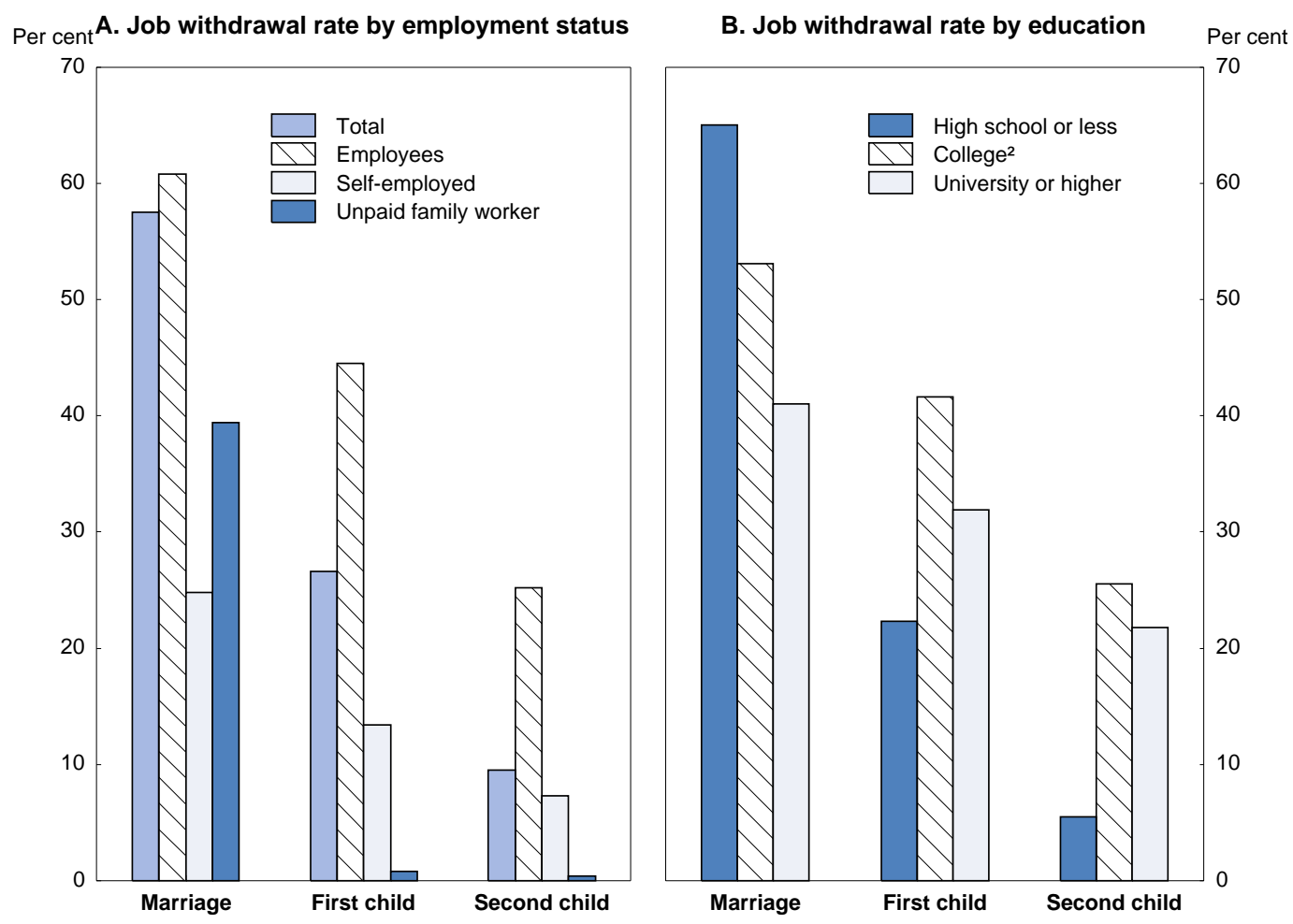

1. The 2007 survey samples for marriage, birth of a first child and a second child are not necessarily identical.

2. Two-year tertiary educational institutions.

Source: Kim (2011).

Another factor discouraging female employment is the gender gap in earnings. In 2012, women employees were paid only $65 \%$ as much as men, the largest gap in the OECD. This gap, which has been virtually unchanged since the mid-1990s, reflects the high share of women engaged in non-regular employment with low wages and the low proportion in management positions. Indeed, although the share of women in management increased from only $9 \%$ during $2007-09$, to $17 \%$ in 2012 , it remains well below the OECD average of $29 \%$. It is necessary to attract women to the labour market by reducing dualism and expanding the weight of performance in setting wages, thereby narrowing the gender wage gap. In short, reforms are needed to offer women the hours, jobs, wages and careers that would encourage them to work.

Korea's youth employment rate is also low by international comparison, due in part to high enrolment in tertiary education, although it has fallen somewhat since the 2008 crisis. Nevertheless, the participation rate for the 15-to-29 age group declined from $44.8 \%$ in 2008 to $43.7 \%$ in 2012 , the lowest on record in Korea. The low and declining rate reflects a mismatch problem, as a large share of youth with tertiary education have difficulty finding suitable employment. At the same time, SMEs, which account for $87 \%$ of employment, face a chronic workforce shortage (2014 OECD Economic Survey of Korea). To achieve the target of a $47.7 \%$ employment rate by 2017 (Table 1), it is essential to resolve the mismatch problem by reducing the overemphasis on higher education, by improving vocational education and providing effective training courses that meet labour market needs (see the 2012 OECD Economic Survey of Korea). 
The departure of workers from firms at a relatively young age in Korea is a waste of human capital. The mandatory retirement age set by firms in 2010 averaged 57 years and many workers leave well before that. Many become unemployed or self-employed in low-productivity activities. The young retirement age reflects the strong link between tenure and wage, which makes older workers expensive. Achieving the $67.8 \%$ employment target for the 55-to-64 age group (Table 1) requires flexible employment and wage systems based on ability rather than age to ensure that older workers remain attractive to firms. The recent decision to require firms with more than 300 workers to set a mandatory retirement age at age 60 or above beginning in 2016 is a step in the right direction. The ultimate aim should be to abolish the right of firms to set mandatory retirement ages, as has been done in a number of OECD countries, which may help break down the link between seniority and wages. ${ }^{3}$

\section{The impact of social welfare programmes is limited}

Korea's social safety net has a number of weaknesses:

- Korea's system of cash benefits and direct taxes is the least redistributive in the OECD in terms of reducing relative poverty and the third weakest in terms of income inequality (OECD, 2013c). This reflects low public social spending, at $9.3 \%$ of GDP in $2012,{ }^{4}$ less than half of the OECD average of $22 \%$, and the limited progressivity of taxes and benefits, although it has improved over the past decade.

- Korea's basic social assistance programme, the Basic Livelihood Security Programme (BLSP), ranks well below the OECD average in terms of generosity. Moreover, its impact is limited by gaps in coverage, which is also a problem for the other pillars of the safety net for the working-age population, namely employment insurance and the in-work earned income tax credit (EITC).

- The tax and benefit system provides weak work incentives for those with low skills, reflecting the simultaneous withdrawal of cash and in-kind benefits at certain earnings levels, thereby encouraging dependency and creating poverty traps (OECD, 2013c).

The BLSP, introduced in 2000, provides cash and a package of in-kind benefits, such as education and health care, to eligible persons living in absolute poverty, defined as an income below the minimum cost of living (MCL) set each year by the government. The MCL is $40 \%$ of the national median income. BLSP benefits, which are intended to boost recipients' income to the MCL, are provided to $3 \%$ of the population. However, $7-8 \%$ of the population has an income below the MCL. The limited coverage reflects the BLSP's strict eligibility criteria on income and asset ownership, which is converted into property income. In addition, those with the possibility of assistance from family members are not eligible for benefits under the "family support obligation rule". The number of recipients has fallen since 2011 due to better enforcement of the eligibility criteria through the Social Security Information System, which has increased transparency about income. BLSP outlays, which amounted to $0.6 \%$ of GDP in 2011, provide a maximum cash transfer (including the housing allowance) equivalent to $26 \%$ of the average income (Figure 5), putting it in the bottom third of OECD countries.

3. Firms accept seniority-based wages, knowing that they can force workers to leave at the retirement age that they set. Prohibiting mandatory retirement would make a strong seniority-wage link too expensive.

4. All comparisons in this paper using GDP are based on SNA1993, which provides time series data back to 1970, rather than on SNA2008, which was released in late March 2014 for the period 2000-13. 
Figure 5 . Income levels provided by cash minimum-income benefits

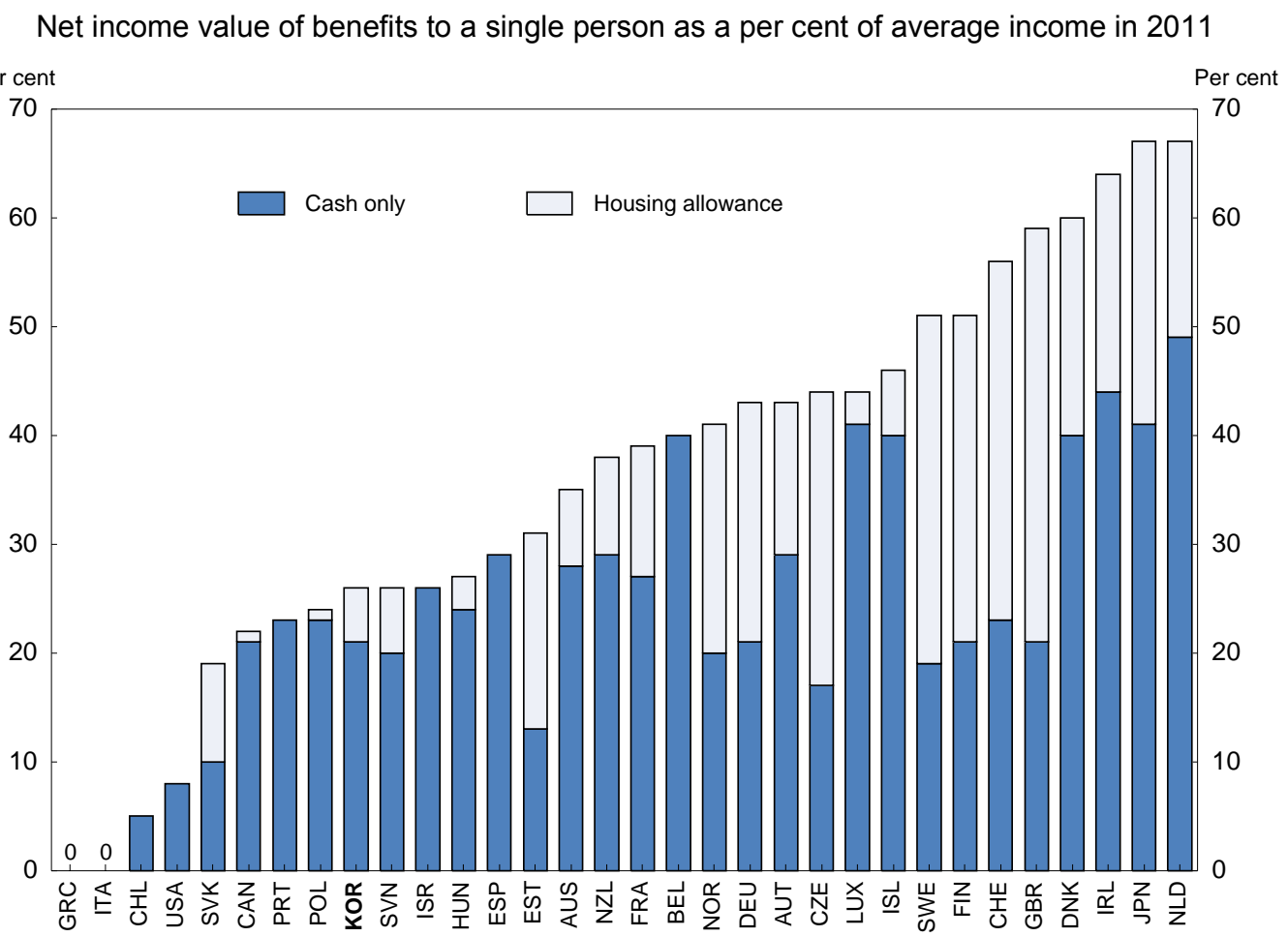

Source: OECD (2013c).

Eligibility criteria for the BLSP were relaxed by easing the family support obligation rule in 2012 and by changing the treatment of housing assets in $2013 .{ }^{5}$ In October 2014, the income criterion for the in-kind benefits, such as for health care and education, will be increased from $40 \%$ to between $40 \%$ and $50 \%$ of the national median income. However, the subsistence cash benefit will still be limited to those with an income below the minimum cost of living. Together, these changes are expected to boost the number of BLSP recipients to 1.8 million, while the phased-in withdrawal of benefits will reduce poverty traps. Further extending the BLSP to cover all persons with an income below the MCL would greatly strengthen the safety net.

Beneficiaries who are able to work are required in principle to participate in training programmes run by central and local governments. In practice, $38 \%$ of able-bodied recipients were granted waivers for various reasons in 2009, suggesting a need to strengthen the training requirements. For those who do participate, the results are poor. Only $6 \%$ of those in the local governments' Self-Reliance Programme were able to escape poverty (Koh, 2011). In general, activation policies have played a small role in Korea, reflecting the low level of spending on active labour market policies at only $0.1 \%$ of GDP, well below the OECD average of $0.5 \%$. In addition, the participation of BLSP recipients has been discouraged by the withdrawal of all benefits once their income reaches the MCL. The 2014 reform to gradually raise the income thresholds for in-kind benefits should help reduce such disincentives.

5. The conversion rate for turning house ownership into monthly income was cut from $4.2 \%$ to $1.0 \%$ in 2013 , although it remains high compared to the rates used in some other OECD countries. Around two-thirds of OECD countries disregard the value of a claimant's home in determining eligibility for social benefits. The conversion rate for other assets in Korea was not changed. 
The impact of the EITC in encouraging work and reducing poverty is limited by its low benefit level and tight targeting compared to other OECD countries (OECD, 2013c). The EITC was initially restricted to couples with children, limiting its coverage to only around $4 \%$ of households. Coverage was extended in 2012 to childless households and some self-employed workers, and in 2014 to single persons. Relaxing the asset test, as for the BLSP, and extending coverage to more self-employed, as transparency about their income improves, would make the EITC more effective. In addition, individuals should be able to receive both the EITC and the BLSP. Finally, a moderate extension of the phase-out range of EITC payments would strengthen work incentives for families with low earning capacities.

Given Korea's rapid population ageing and the potential cost of rapprochement with North Korea, it is important to be cautious in increasing social spending. Indeed, population ageing alone is projected to boost public social spending from less than $10 \%$ of GDP in 2012 to $29 \%$ by 2060 under the current framework, according to the government. Revenue to finance any additional spending should be raised by pro-growth tax reform (Jones, 2008).

\section{Enhancing the contribution of education to social cohesion}

\section{Ensuring access to high-quality early childhood education and care (ECEC)}

ECEC plays an essential role in improving the educational development of children as well as promoting social mobility and income equality. Empirical work has established that fundamental cognitive and non-cognitive abilities are created well before the age of five. Investment in pre-primary education thus provides high rates of return by enhancing later school achievement. Korea has gradually increased public spending on ECEC from a low level in recent years. In March 2013, it introduced a universal childcare subsidy to all parents with children aged five and under, regardless of their financial conditions. ${ }^{6}$

For children between ages three and five, $88 \%$ are enrolled in ECEC, equally split between childcare and kindergarten. The two systems have been segmented, with separate facilities and different objectives and curricula (Jones, 2013). The educational quality of kindergarten, under the Ministry of Education, is considered by parents to be superior to that of childcare, which is administered by the Ministry of Health and Welfare and has more of a social-welfare orientation. Private childcare is subject to price controls, in contrast to kindergartens, which are thus more expensive than childcare. In addition, a large number of children, particularly in higher-income families attend private institutions, known as hagwons, instead of or in addition to childcare and kindergarten. Hagwons are primarily focused on academic subjects, particularly foreign languages and mathematics. To promote social cohesion, it is important to ensure that the lower-cost childcare centres also provide high-quality instruction by:

- Relaxing price ceilings and entry barriers for childcare to promote quality through competition, while ensuring its affordability by increasing subsidies on a means-tested basis.

- Setting up an integrated system for accreditation, monitoring and information common to both kindergartens and childcare services so that parents can make informed decisions about ECEC.

- Ensuring effective implementation of the common curriculum for five-year-olds in childcare and kindergarten that began in 2012 and continuing the harmonisation for three and four-year-olds.

- Establishing common regulations and standards, including for staff qualifications and staff-child ratios, for all children ages three to five, regardless of whether they attend kindergarten or

6. In March 2012, subsidies had been extended to children aged 0 to 2 and to 5-year-olds. For 3 and 4-yearolds, subsidies were given to those in the lower $70 \%$ of the income distribution. 
childcare. The goal should be to raise the qualifications and pay of childcare staff. One option is the gradual integration of kindergarten and childcare.

\section{Reducing the reliance on after-school tutoring}

Reliance on hagwons is also important for secondary students. Indeed, the share of students participating in after-school tutoring was the second highest among OECD countries in every subject except science in 2012 (Figure 6). Total spending on private tutoring increased from 1.2\% of GDP in 1999 to $1.8 \%$ in 2010 , representing $7.9 \%$ of average household disposable income (2012 OECD Economic Survey of Korea). A government survey that asked parents why they send their children to hagwons found that the most important reason was to gain entry to prestigious universities, which select students primarily based on entrance exam scores (Ministry of Education, 2011). Academic credentialism - the emphasis on where a person studied rather than on their abilities, accomplishments and potential - is strong in Korea, based on a well-known ranking of universities (Chang, 2009). The weakness of schools was also cited by parents, making private tutoring important to compensate for schools' shortcomings and to provide services tailored to students' individual needs. Given the high competition to enter top universities, though, private tutoring would likely play an important role regardless of the quality of schools.

Figure 6. The percentage of students attending after-school lessons in Korea is exceptionally high

Percentage of students by hours per week in 2012
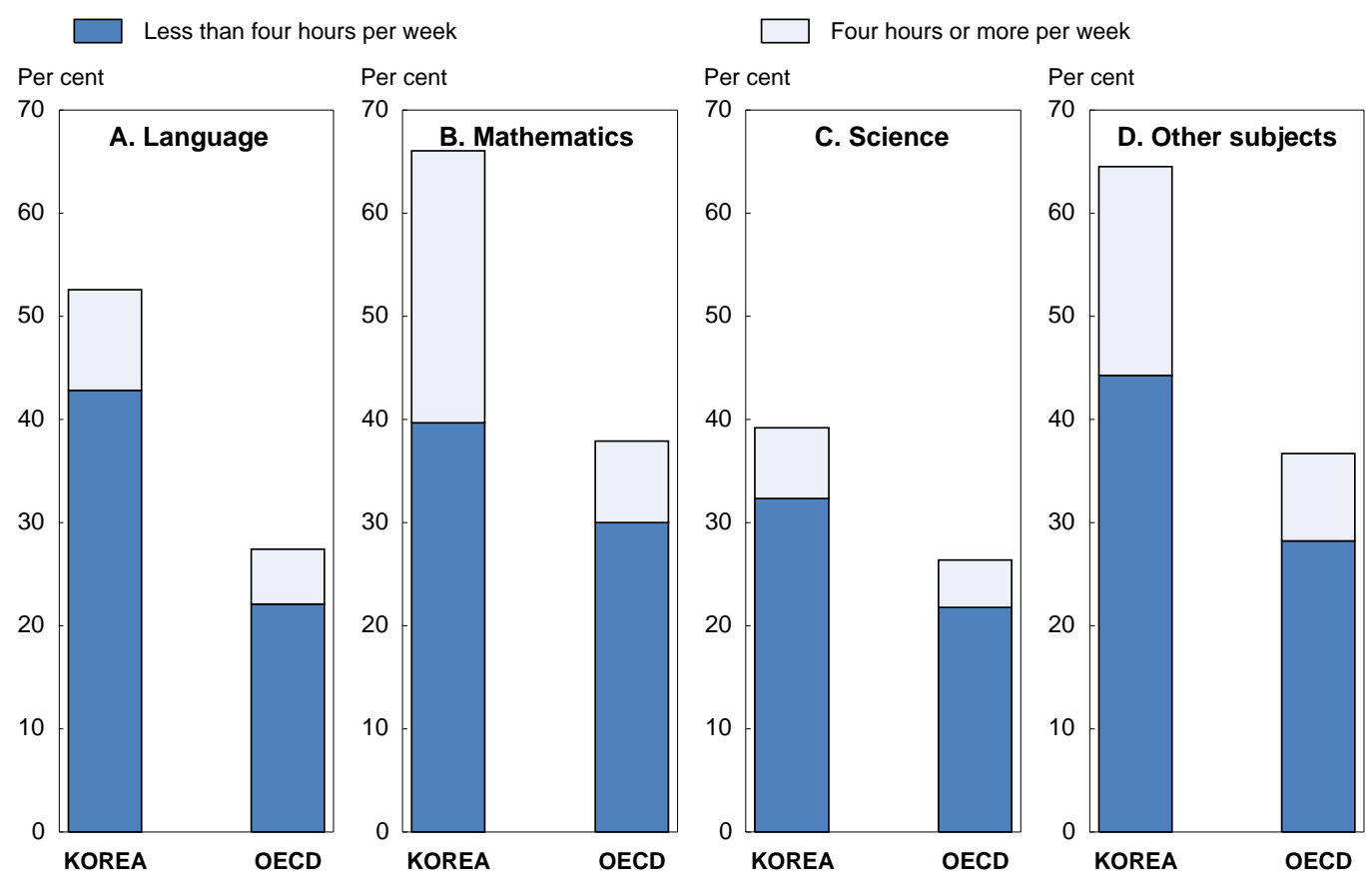

Source: OECD (2013b).

Participation in and spending on private tutoring are highly correlated with family income and in turn with admittance to high-ranking universities, which are a key determinant of career prospects and income. Only $34 \%$ of students from families with a monthly income below 1 million KRW (\$963) participated in private tutoring in 2010, compared to $80 \%$ for those from families earning 4 to 5 million KRW (Figure 7). Similarly, the amount of outlays per student in private tutoring is four times higher for the middle-income group than for the lowest-income group. For households with income over 6 million KRW per month, enrolment rates rise to $84 \%$, while outlays per month reach around 430 thousand KRW. 
Figure 7. Household income is closely linked with outlays and participation in private tutoring

In 2011

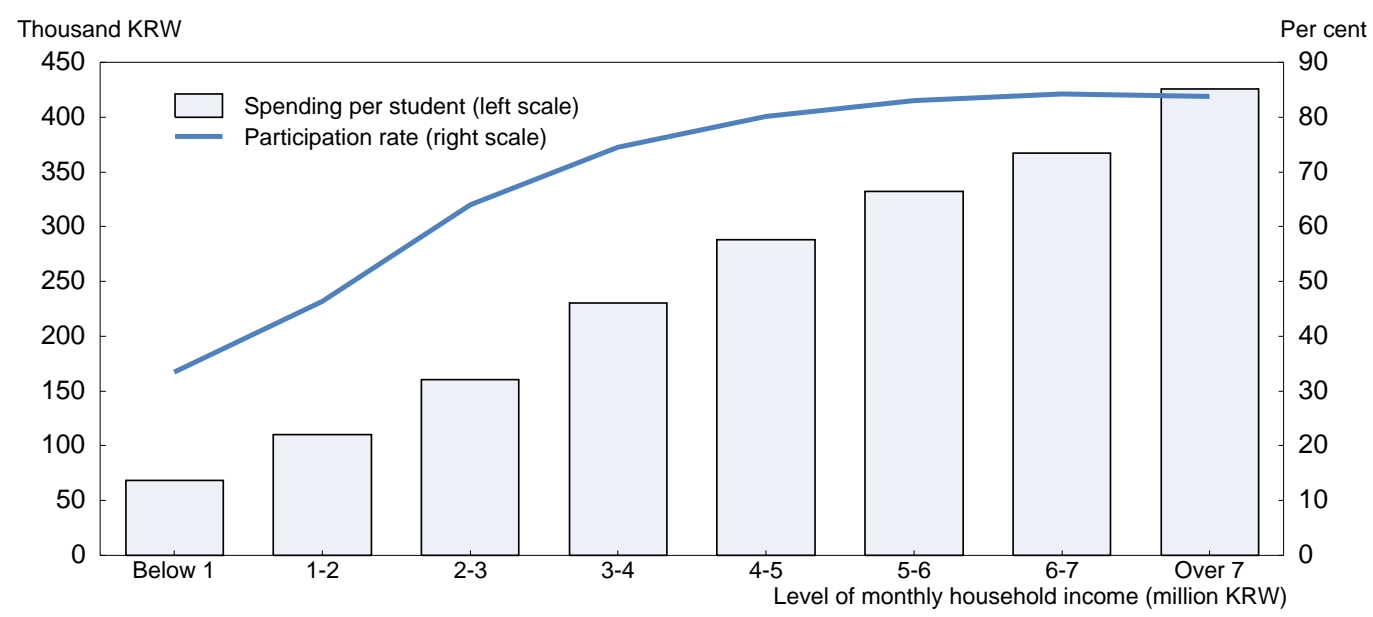

Source: OECD (2014b).

Equal opportunity is thus undermined by the heavy reliance on private tutoring, prompting the government to take measures to reduce its role. First, the government introduced in 2007 "the admissions officer" system, which gives greater weight to criteria other than the university entrance exam, such as school grades, essays and extra-curricular activities, to improve the university admission process. The new approach, which is now called the "school records" system, covered $13.5 \%$ students admitted to four-year universities in 2013. There is a need for caution, though, as reliance on more subjective criteria opens up opportunities for favouritism, given the importance of social connections. The reliance on multiple-choice exams has provided legitimacy to the university entrance process. Second, the government has made public after-school tutoring more accessible to low-income students by further expanding Internet and broadcast teaching systems and increasing after-school programmes in schools. Third, the government regulates the operating hours and fees charged by hagwons.

While the school records system and the increased access to public after-school education are steps in the right direction, it is important to address the fundamental causes driving private tutoring. Parents' responses to the 2011 government survey focused on three issues. First, improving the quality of schools would enable students to acquire sufficient education without private tutoring. Second, creating more diverse schools, an objective the government is pursuing through its plan to establish 300 "autonomous" high schools, would help meet students' needs. Third, strengthening vocational education would reduce the over-emphasis on higher education and the need for private tutoring. Meister schools, based on the German model of training master craftsmen, have been successful since their introduction in 2008 and should help address the labour market mismatch discussed above. Finally, given that university tuition is the third highest in the OECD area, it is important to expand the availability of public loans for tertiary education, with repayment contingent on income after graduation. Loans, scholarships and grants to students amounted to only $9 \%$ of public spending on tertiary education in 2010 , far below the $22 \%$ OECD average.

7. Of around 17 thousand hagwons or tutors investigated in 2013, nearly 2 thousand were found to have violated rules regulating fees paid by parents and the 10 p.m. curfew. 


\section{Reducing the high rate of poverty among the elderly}

Poverty in Korea is concentrated among the elderly. While the relative poverty rate - defined as an income below half of the national median - for the working-age population was below the OECD average in $2011,49 \%$ of the population aged 65 and over lived in relative poverty. This is the highest proportion among OECD countries and far above the OECD average of $13 \%$. The government has no data on the share of elderly in absolute poverty (an income below the minimum cost of living, which is $40 \%$ of the national median income). It is likely to be significant, as the share of Korea's national population in absolute poverty, at $7-8 \%$, is about half of that in relative poverty. In $2012,26 \%$ of the elderly had an income below 450 thousand KRW, well below the minimum cost of living of 553 thousand KRW (MHW, 2013), which would place them in absolute poverty. In sum, the generation responsible for Korea's economic miracle has been poorly rewarded. Addressing the high elderly poverty rate is essential to promote social cohesion in Korea. While the suicide rate of youth is close to the OECD average, rising poverty among the elderly contributed to an increase in their suicide rate from 34 (per 100 thousand persons) in 2000 to 72 in 2010, far above the OECD average of 22.

The high elderly poverty rate reflects a decline in family support before other private and public sources of old-age income have matured. The number of elderly living alone, who face a particularly high poverty rate of $71 \%$ (OECD, 2011), rose from 0.5 million in 2000 to 1.25 million (a quarter of the elderly) in 2010. In contrast to many OECD countries, where population ageing and development of public pensions occurred over a long time span, rapid population ageing in Korea has left it less prepared. Many elderly have failed to prepare financially, assuming that their children would care for them.

\section{Overview of the income support system for Korea's elderly}

Korea has created a multi-pillar system to support its elderly population (Figure 8$).{ }^{8}$ However, it is insufficient at present to prevent a high poverty rate among the elderly, reflecting its early stage of development and vigorous competition among diverse programmes to expand their coverage without an overall systemic plan (Kim, 2013).

\section{The zero pillar: social welfare programmes}

The elderly can receive benefits from the Basic Livelihood Security Programme (BLSP, discussed above) and the Basic Old-Age Pension (BOAP). The share of the elderly receiving BLSP benefits is $6 \%$, which is likely to be far below the share living in absolute poverty, as noted above. The low share of recipients reflects the income criterion that includes asset and the "family support obligation rule", which excludes elderly with the possibility of assistance from family members. However, the tradition of family support has weakened in recent years. Nevertheless, the government prefers to keep the rule in order to encourage families to care for their elderly relatives.

The BOAP, which was introduced in 2008 , covers nearly $70 \%$ of the elderly, with a benefit that reached 97 thousand KRW (around $\$ 93$ or 16\% of the minimum cost of living) in 2014. The BOAP thus spreads resources very thinly over a large segment of the older population, compared to similar programmes in other OECD countries. In 2011, 31 OECD countries, including Korea, had noncontributory benefits that were means-tested, with an average benefit equal to $31 \%$ of economy-wide average earnings (Figure 9). Korea's BOAP benefit was the least generous, while its coverage was exceptionally large at $67 \%$ of the elderly, compared to an OECD average of $28 \%$ (Panel B). The BOAP has been unable to prevent a significant rise in the elderly poverty rate and Gini coefficient since 2007.

8. For further information on the structure of the elderly income support system, see Jones and Urasawa (2014). 
Figure 8. Korea's elderly income support system has multiple pillars

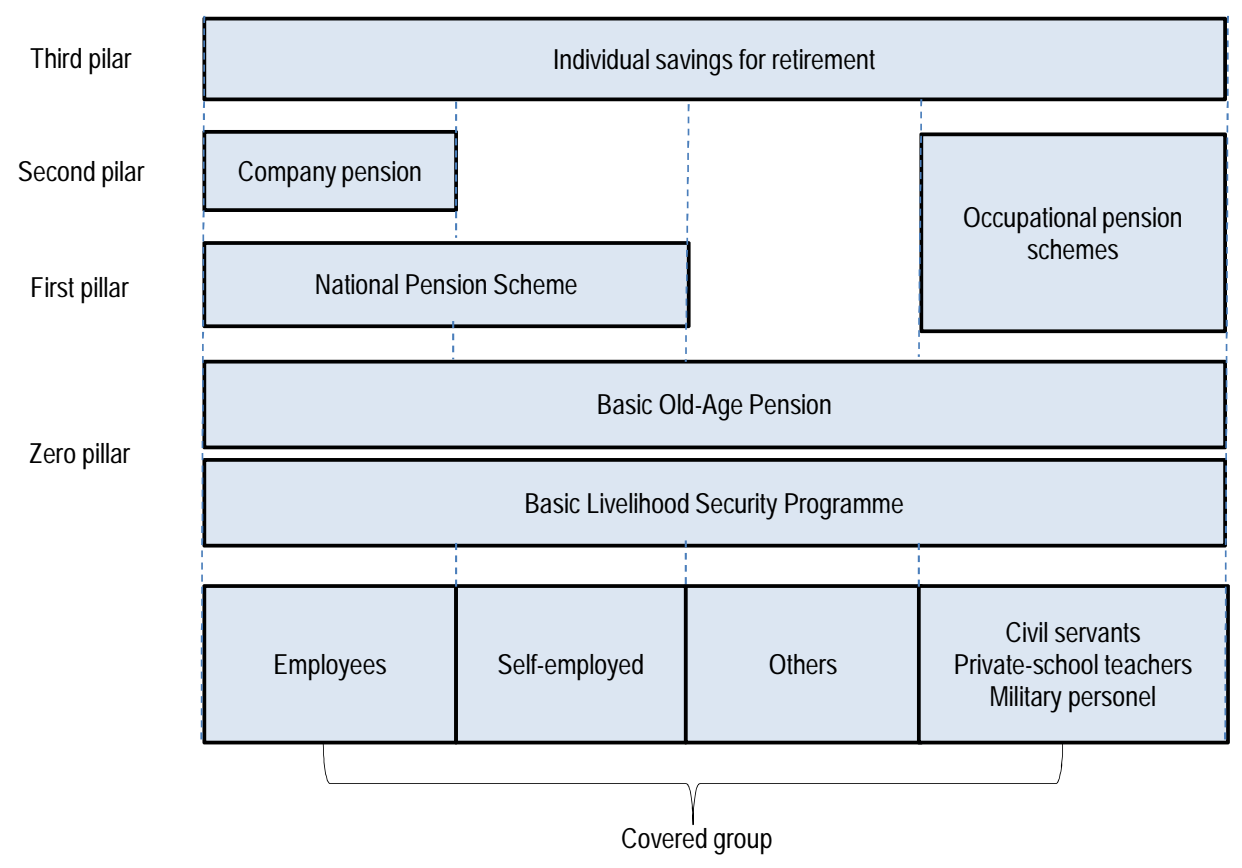

Source: Kim (2013).

The first pillar: the National Pension Scheme (NPS) and occupational pension schemes

In 2013, 29\% of the elderly received old-age pensions from the NPS (Table 2). The average pension benefit was small at 310 thousand KRW per month (about \$298), a little over half of the minimum cost of living. Moreover, the gender gap in NPS coverage and benefits is large; $40 \%$ of men received benefits in 2011 compared to only $15 \%$ of women. The limited role of the NPS reflects its relatively recent introduction in 1989 and the large share of the population that does not participate in the Scheme. In 2012, 15.7 million persons paid contributions (NPS, 2012a), only $43 \%$ of the working-age population and far below the $80-100 \%$ in other advanced countries (Lee, 2012). The low share reflects a lack of trust in the pension system, as well as the large number of self-employed, non-regular workers and employees at SMEs, who can evade contributions. In 2011, only $38 \%$ of non-regular workers were covered in their workplaces compared to $79 \%$ of regular workers. Participation has also been discouraged by the cut in the targeted replacement rate from an initial $70 \%$ to $50 \%$ for a worker with 40 years of contributions, and the rate is set to decline further to $40 \%$ by 2028 .

Apart from the NPS, three stand-alone public-sector pension schemes - for civil servants, the military and private-school teachers - cover 1.5 million public-sector workers ( $4 \%$ of the working-age population). The occupational schemes rely increasingly on government funding because of the relative generosity of their pension benefits compared to the NPS and the rising number of retired public-sector officials and their increasing life expectancy (Kim and Moon, 2011). In 2009, government spending for the civil service scheme amounted to $0.6 \%$ of GDP and, despite reforms enacted that year, it is expected to reach $1.1 \%$ in 2030 . 
Figure 9. Basic, non-contributory pensions in OECD countries

In 2012
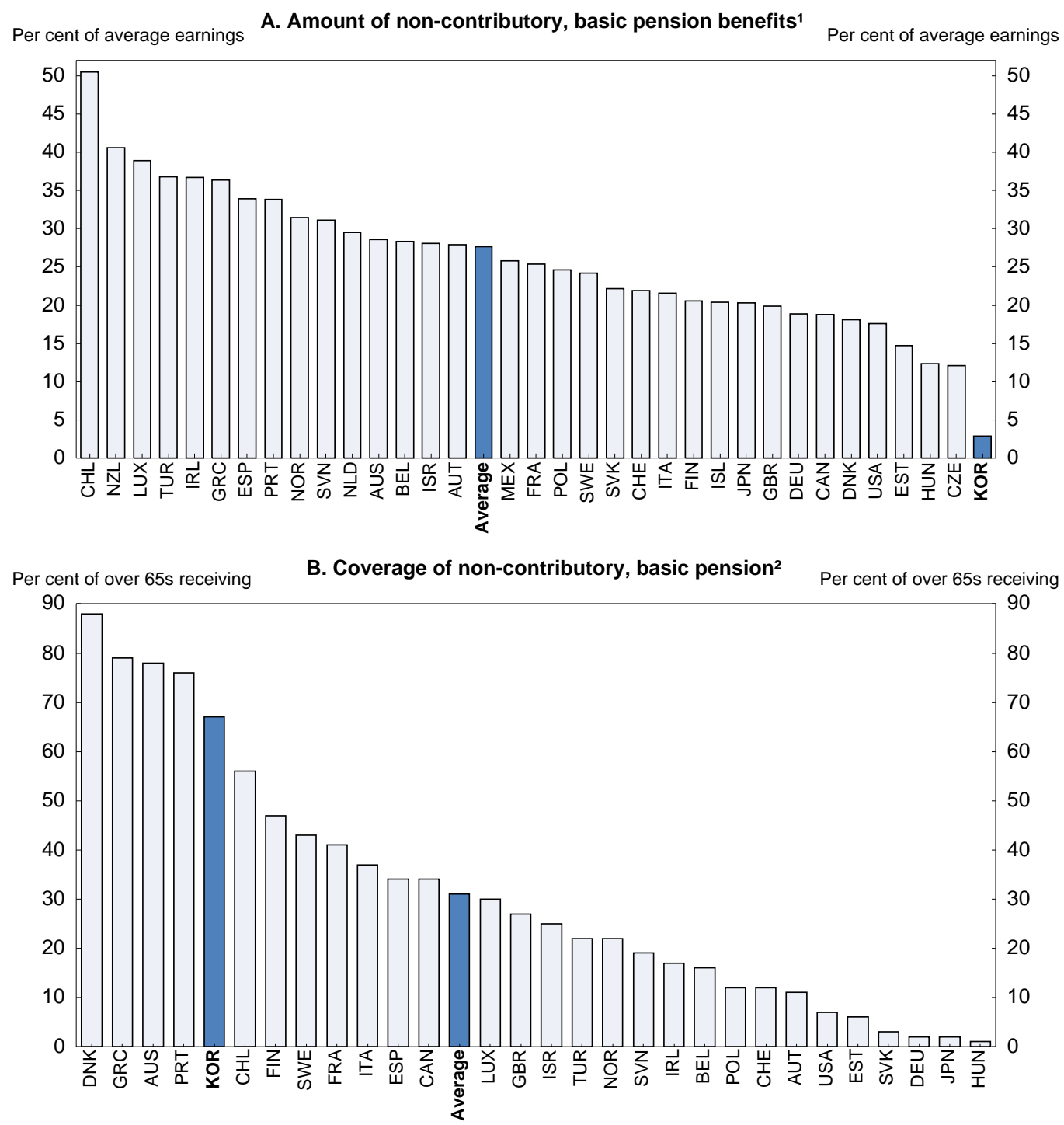

1. As a per cent of economy-wide average earnings.

2. As a per cent of the population aged 65 and over.

Source: OECD (2013a).

The second pillar: the retirement allowance and the company pension system

The weakness of the NPS and the decline in family support has left a void that is to be filled in part by company pensions, which were launched in 2005. Company pensions are intended to replace the so-called retirement allowance, which requires firms to pay departing employees a lump-sum equivalent to at least one month of wages per year of work. The retirement allowance, which became mandatory in 1961, was intended to support the unemployed and retirees in the absence of unemployment insurance and pensions. However, it is not a secure source of retirement income, as it is partially unfunded. Moreover, given average job tenure of only six years in Korea, most workers receive the retirement allowance numerous times during their working life. About $70 \%$ of workplaces with a retirement allowance have paid the 
allowance to workers at least once prior to their retirement, which encourages its use for purposes other than retirement income.

Table 2. Long-term projections of the coverage of the National Pension Scheme

In thousand people

\begin{tabular}{|c|c|c|c|c|c|c|c|c|}
\hline & \multicolumn{2}{|c|}{ Population } & \multicolumn{2}{|c|}{ Insured persons } & \multicolumn{4}{|c|}{ Pension recipients (over 65) } \\
\hline & \multirow{2}{*}{$\begin{array}{c}18-59 \\
(A)\end{array}$} & \multirow{2}{*}{$\begin{array}{l}\text { Over } 65 \\
\text { (B) }\end{array}$} & \multirow[b]{2}{*}{ (C) } & \multirow[b]{2}{*}{ C/A } & \multicolumn{2}{|c|}{ Old Age } & \multicolumn{2}{|c|}{ Disability or survivor } \\
\hline & & & & & (D) & $\mathrm{D} / \mathrm{B}$ & $(\mathrm{E})$ & $E / B$ \\
\hline 2013 & 32316 & 6138 & 20396 & 63.1 & 1782 & 29.0 & 233 & 3.8 \\
\hline 2020 & 31395 & 8084 & 20367 & 64.9 & 2764 & 34.2 & 547 & 6.8 \\
\hline 2030 & 27415 & 12691 & 18627 & 67.9 & 5194 & 40.9 & 1173 & 9.2 \\
\hline 2040 & 23792 & 16501 & 16823 & 70.7 & 8972 & 54.4 & 1774 & 10.8 \\
\hline 2050 & 21045 & 17991 & 15479 & 73.6 & 12310 & 68.4 & 2187 & 12.2 \\
\hline 2060 & 17730 & 17622 & 13573 & 76.6 & 13857 & 78.6 & 2230 & 12.7 \\
\hline
\end{tabular}

Source: National Pension Research Institute (2013).

The retirement allowance also has negative side effects on the labour market. First, it encourages the hiring of non-regular workers, as less than half are eligible for the allowance (OECD, 2013c). Second, it discourages firms from keeping older workers, given that the allowance is linked to the final salary, which rises with age in Korea's seniority-based wage system. Nevertheless, the retirement allowance remains popular with workers, slowing the spread of company pensions. Its popularity is due in part to favourable tax treatment, which allows the lump sum to be taxed over a number of years at low rates.

The company pension system allows firms to transform the retirement allowance into a defined benefit (DB) or a defined contribution scheme (DC), based on an agreement between management and employees. Companies that introduce a pension system are exempt from paying the retirement allowance, although many still do. The replacement rate of company pensions is estimated to be $12.5 \%$ (Chung, 2010). By 2012, only $13.4 \%$ of firms had established company pensions (Table 3 ). As the share is highest among large firms, $24.7 \%$ of employees were enrolled in company pensions $(46 \%$ of workers who have been employed for at least one year), with two-thirds in DB schemes. Regular workers account for the vast majority of those enrolled in company pensions. The business sector's resistance to the company pension system reflects in part the requirement that firms must entrust at least $60 \%$ of the funds to financial institutions in the case of DB schemes and $100 \%$ in the case of DC schemes, in contrast to the retirement allowance, which does not have to be funded outside the firm. Moreover, contributions to company pensions can be as large as those for the retirement allowance.

\section{The third pillar: individual pension accounts}

Voluntary individual pension accounts, which were introduced in 1994, allow individuals to choose personal pension products offered by insurance companies, banks and asset management companies. They are allowed a tax credit of up to $12 \%$ of the amount placed in the accounts up to a ceiling of 4 million KRW (\$3 850) a year and taxation is deferred until they start receiving benefits at age 55 . The replacement rate of the individual accounts has been estimated at 7.5\% (Chung, 2010). The total amount of assets in individual accounts increased from $4.5 \%$ of GDP in 2008 to $6.5 \%$ in 2013, while the number of contracts rose by $55 \%$ to 6.3 million. However, assuming one contract per person, the number of voluntary individual retirement accounts would cover only $17 \%$ of the working-age population. Moreover, a substantial number of individuals withdraw their funds before reaching age 55 . The share of investors closing their account rises from $28 \%$ after five years to $48 \%$ after ten years. 
Table 3. Enrolment in the company pension system

\begin{tabular}{|c|c|c|c|c|c|c|c|}
\hline & \multirow{2}{*}{$\begin{array}{l}\text { Share of } \\
\text { firms with } \\
\text { company } \\
\text { pensions }\end{array}$} & \multirow{2}{*}{$\begin{array}{l}\text { Employees enrolled in } \\
\text { company pensions }\end{array}$} & \multirow{2}{*}{$\begin{array}{l}\text { Share of total } \\
\text { employees }\end{array}$} & \multirow{2}{*}{$\begin{array}{c}\text { Share of employees } \\
\text { employed at least } \\
\text { one year }^{1}\end{array}$} & \multicolumn{3}{|c|}{ Enrolled employees by type of plan } \\
\hline & & & & & DB plan & DC plan & $\mathrm{IRP}^{2}$ \\
\hline & Per cent & Thousand employees & Per cent & Per cent & Per cent & Per cent & Per cent \\
\hline $\begin{array}{l}2006 \\
2008 \\
2010 \\
2012 \\
\end{array}$ & $\begin{array}{r}1.2 \\
3.6 \\
6.4 \\
13.4 \\
\end{array}$ & $\begin{array}{ll} & 213 \\
1 & 115 \\
2394 \\
4377 \\
\end{array}$ & $\begin{array}{r}1.4 \\
6.9 \\
14.1 \\
24.7 \\
\end{array}$ & $\begin{array}{r}3.1 \\
15.2 \\
27.0 \\
46.0\end{array}$ & $\begin{array}{l}39.2 \\
63.3 \\
68.8 \\
63.3 \\
\end{array}$ & $\begin{array}{l}43.6 \\
31.1 \\
28.2 \\
34.7 \\
\end{array}$ & $\begin{array}{r}17.2 \\
5.6 \\
3.0 \\
2.0 \\
\end{array}$ \\
\hline
\end{tabular}

1. Workers who have worked one year or longer at a company are eligible for company pensions.

2. Individual Retirement Pension.

Source: Ministry of Employment and Labour.

\section{Longer-term challenges to reducing elderly poverty}

Longer-term concerns include demographic change, the limited impact of the NPS and its financial sustainability. Elderly poverty is likely to be exacerbated during the coming decades by population ageing. The fertility rate fell from 4.5 in 1970 to 1.2 in 2002 and remains close to that level, the lowest in the OECD, while life expectancy has risen to the OECD average. As a result, Korea is projected to face the most rapid population ageing in the OECD, transforming its population from the fourth youngest in 2012 to the third oldest in 2050 (Figure 10). The number of working-age persons is projected to fall from 6.0 per elderly in 2010 to 1.3 in 2050, which may tend to further reduce family support for the elderly.

Figure 10. Population ageing in Korea is projected to be the fastest in the OECD area

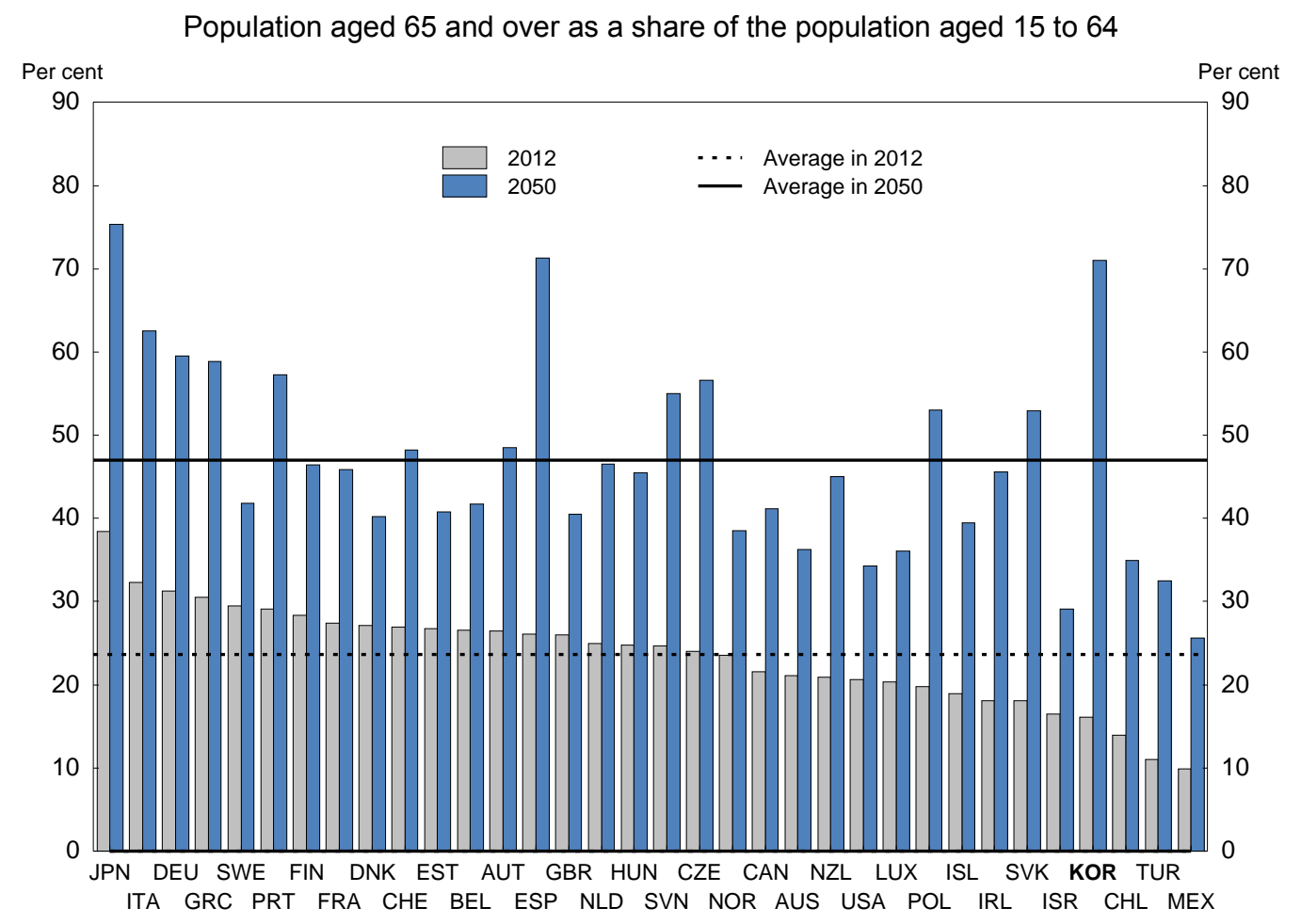

Source: OECD Demography and Population Database. 
The NPS will be insufficient to significantly reduce poverty among the elderly given its low coverage, the limited contribution history of pension recipients and the low targeted replacement rate. According to the government's 2013 projection, only $40.9 \%$ of the elderly in 2030 will receive old-age pensions (Table 2). Moreover, their average contribution period is projected to be less than 20 years, less than half of the 40 years on which the $40 \%$ replacement rate is based. In addition to the gaps in coverage, this reflects early departure from firms even before the mandatory retirement age, which firms set at an average age of 57 in 2010. With a contribution period of less than 20 years, the average replacement rate would be less than $20 \%$. In addition to the low average level, pension benefits will vary widely, reflecting high wage inequality, as noted above.

The NPS is not financially sustainable according to the government's 2013 projection, despite large social security surpluses at present that are projected to boost the National Pension Fund to $50 \%$ of GDP by 2035 (NPRI, 2013). ${ }^{9}$ Under the current parameters (a 9\% contribution rate, a hike in the pension eligibility age from 61 to 65 by 2033 and a $40 \%$ replacement rate), outlays would surpass revenues in 2044 (Table 4). The Fund would be exhausted by 2060, when its annual deficit would reach $4.1 \%$ of GDP.

Table 4. Long-term projections of the National Pension Scheme's financial balance

\begin{tabular}{|c|c|c|c|c|c|c|c|c|}
\hline & \multicolumn{2}{|c|}{ National Pension Fund } & \multicolumn{2}{|c|}{ Income } & \multicolumn{2}{|c|}{ Expenditure } & \multicolumn{2}{|c|}{ Balance } \\
\hline & $\begin{array}{l}\text { Trillion } \\
\text { KRW }\end{array}$ & $\begin{array}{c}\text { Per cent of } \\
\text { GDP }\end{array}$ & $\begin{array}{l}\text { Trillion } \\
\text { KRW }\end{array}$ & $\begin{array}{c}\text { Per cent of } \\
\text { GDP }\end{array}$ & $\begin{array}{l}\text { Trillion } \\
\text { KRW }\end{array}$ & $\begin{array}{l}\text { Per cent } \\
\text { of GDP }\end{array}$ & $\begin{array}{l}\text { Trillion } \\
\text { KRW }\end{array}$ & $\begin{array}{l}\text { Per cent } \\
\text { of GDP }\end{array}$ \\
\hline 2013 & 417.7 & 31.1 & 52.2 & 3.9 & 14.6 & 1.1 & 37.7 & 2.8 \\
\hline 2020 & 847.2 & 39.3 & 109.1 & 5.1 & 33.9 & 1.6 & 75.2 & 3.5 \\
\hline 2030 & 1732.4 & 47.8 & 186.9 & 5.2 & 90.0 & 2.5 & 97.0 & 2.7 \\
\hline 2040 & 2494.5 & 47.4 & 258.4 & 4.9 & 213.8 & 4.1 & 44.7 & 0.9 \\
\hline 2043 & 2561.5 & 44.2 & 277.6 & 4.8 & 267.3 & 4.6 & 10.3 & 0.2 \\
\hline 2044 & 2558.7 & 42.7 & 283.7 & 4.7 & 286.5 & 4.8 & -2.8 & 0.0 \\
\hline 2045 & 2541.4 & 41.1 & 289.4 & 4.7 & 306.8 & 5.0 & -17.4 & -0.3 \\
\hline 2050 & 2200.5 & 30.5 & 309.8 & 4.3 & 414.1 & 5.7 & -104.3 & -1.4 \\
\hline 2060 & -280.7 & -2.9 & 263.4 & 2.8 & 657.8 & 6.9 & -394.4 & -4.1 \\
\hline
\end{tabular}

Source: National Pension Research Institute (2013).

\section{Addressing elderly poverty, while ensuring the long-run sustainability of the NPS}

A well-designed multi-pillar approach based on a social consensus is needed to ensure adequate retirement income and reduce elderly poverty. This should include carefully-targeted social spending, reforms to public pension systems, and measures to boost private savings for old age by developing the company pension system and individual pension savings. Together, the pillars should aim at an overall replacement rate of around 70\% (Antolin, 2009). All of the components of a multi-pillar system have been established in Korea during the past 25 years but are still at an early stage of development. Moreover, it is essential that the pillars function smoothly together (Kim, 2013).

\section{Immediate priorities to reduce elderly poverty}

The top priority in the short run is to improve social welfare programmes to ensure an adequate minimum level of income for the elderly. The 2014 legislation to double the BOAP to 200 thousand KRW

9. The government's fiscal objective is to balance the consolidated central government budget (excluding social security). The resulting surpluses have led to a rapid increase in the National Pension Fund and made the government a net creditor with net assets equal to $35.9 \%$ of GDP in 2012. 
(about \$193) per month, while keeping the coverage virtually unchanged, ${ }^{10}$ would raise government outlays by around 1\% of 2012 GDP over 2014-17. Although there is no estimate of the impact of the expansion of the BOAP on the relative poverty rate of the elderly, which is $49 \%$, it is likely to be limited, leaving the poverty rate far above the $13 \%$ OECD average. Moreover, it is uncertain what impact it would have on the share of elderly in absolute poverty.

Inasmuch as the BLSP has not achieved the goal of ensuring that all poor have an income that at least matches the minimum cost of living, the BOAP could play that role for the elderly. Given the budget constraint, this would require narrowing the coverage of the BOAP to provide larger benefits to the elderly below the minimum cost of living, in line with its stated goal of aiding the "financially distressed" (Yun, 2013), so that they can escape absolute poverty. As poverty and income inequality are much higher among the elderly than the working age population, narrowing the BOAP's coverage and increasing its benefits is appropriate.

With the 2014 reform increasing the threshold for in-kind benefits from $40 \%$ to $40 \%-50 \%$ of median income, the BLSP should be used to top up the income of poor elderly. The proportion of elderly receiving the BLSP should be increased from the current $6 \%$ by further relaxing the treatment of home ownership by the BLSP and the "family support obligation rule". Finally, the government should ensure that all the elderly who are eligible for the BLSP actually receive it (OECD, 2013c). Measures to enhance the employability of older workers, as part of the $70 \%$ roadmap, would also help reduce poverty.

\section{Ensuring the sustainability of the public pensions}

The NPS faces the challenge of expanding its coverage to alleviate poverty while ensuring its longterm solvency. There are three options to achieve sustainability - cutting pension benefits, raising the pension eligibility age and hiking the contribution rate. With the replacement rate set to fall to $40 \%$, further cuts in pension benefits might increase the share of elderly in poverty. As for the pension eligibility age, it is already set to rise from 61 to 65 by 2033, which will offset gains in life expectancy, although a number of OECD countries will have higher eligibility ages by that point. However, under current labour practices, a more rapid hike in the pension eligibility age would lengthen the gap between when workers leave firms and when they can receive a public pension.

The best option, therefore, is to raise more revenue. Although some countries rely on general tax revenue to finance pensions, this would not be appropriate in Korea, where only $41 \%$ of the elderly will receive an NPS pension in 2030. Relying on general tax revenue to fund the NPS would, in effect, transfer income from low-income persons, such as non-regular workers and those in SMEs, who are less likely to participate in the NPS, to higher-income persons. Instead, the priority is to raise the contribution rate, which has been set at 9\% since 1998, the second lowest in the OECD area and well below the OECD average of $19.6 \%$ (Figure 11). This has helped limit Korea's marginal tax wedge on labour, which is the third lowest in the OECD area. The 2013 government projection estimated that balancing the NPS budget through 2083 would require boosting the contribution rate to $14.1 \%$ by 2015 . However, previous attempts to raise it have been rejected by the National Assembly and the current government has ruled out a hike in the rate during its term, which ends in 2018. Given the speed of population ageing, the contribution rate should start to be raised as soon as possible. Reforms are also needed to contain the cost of the three public-sector occupational pensions. The priority is to scale back the generosity of pension benefits, which have been maintained at high levels while the NPS was cut (Kim and Moon, 2011).

10. Of the recipients, $60 \%$ will receive the full 200 thousand KRW, while the remainder will get between 100 thousand and 200 thousand KRW depending on their income. The original campaign promise of providing universal coverage of the increased BOAP was ruled out as too expensive. 
Figure 11. International comparison of pension contribution rates

As a per cent of gross earnings in $2012^{1}$

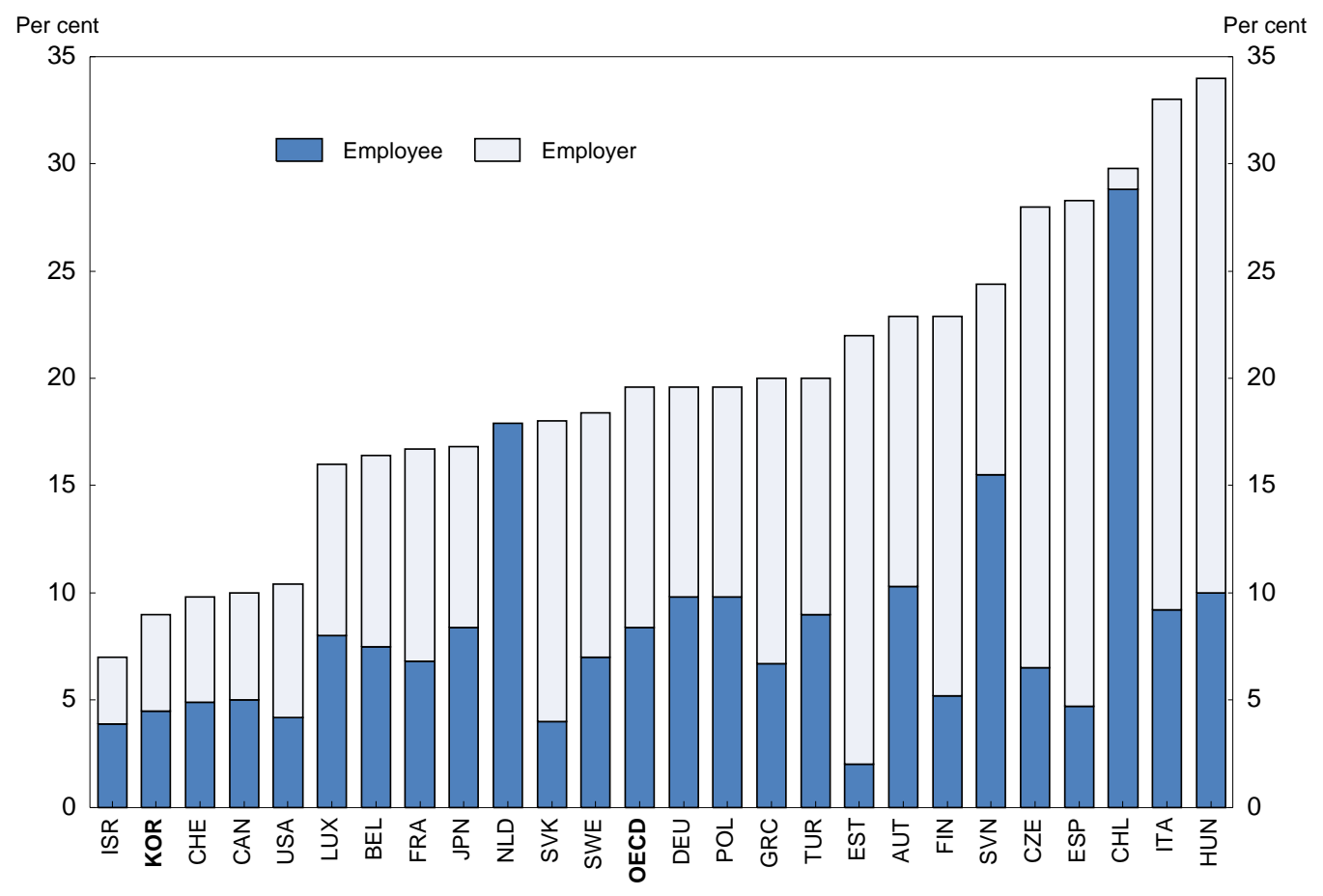

1. For 25 countries as some OECD countries have no separate pension contributions or private pensions only.

Source: OECD (2013a).

\section{Enhancing the effectiveness of the NPS against elderly poverty}

Ensuring adequate financing of the NPS would strengthen confidence in it, thereby increasing participation and the share of the population that will receive NPS pensions. The low participation also reflects the preference of workers and firms to avoid the burdens of paying contributions, pointing to the need for better enforcement (Lee, 2012), in particular to increase the compliance of the self-employed and to enhance transparency about their income. Combining the collection of taxes and social contributions would improve transparency about the income of the self-employed. Raising the share of non-regular workers who contribute to the NPS at their workplace from the current $38 \%$ is another priority.

To achieve a 70\% overall replacement rate from all pillars combined will be difficult in Korea given the low NPS benefits. The gross replacement rate is $40 \%$, the sixth lowest in the OECD and well below the $54 \%$ OECD average for mandatory pension schemes (Figure 12). As noted above, the government's longterm projections (Tables 2 and 4) are based on a contribution period of less than 20 years over 2030-40, implying that the average replacement rate will be less than $20 \%$ even after the NPS matures in 2028. Not surprisingly, nearly one-half of those surveyed in 2012 expect that the NPS pension benefit will be insufficient to cover their basic living expenses when they are old (Seok et al., 2012). The company pension system, which is concentrated among larger firms where wages are significantly higher, and individual pension saving accounts, are estimated to have a combined replacement rate of only $20 \%$ (Chung, 2010). Consequently, achieving the $70 \%$ replacement would likely require a large rise in social welfare spending. 
Figure 12. Korea's pension replacement rate is one of the lowest in the OECD

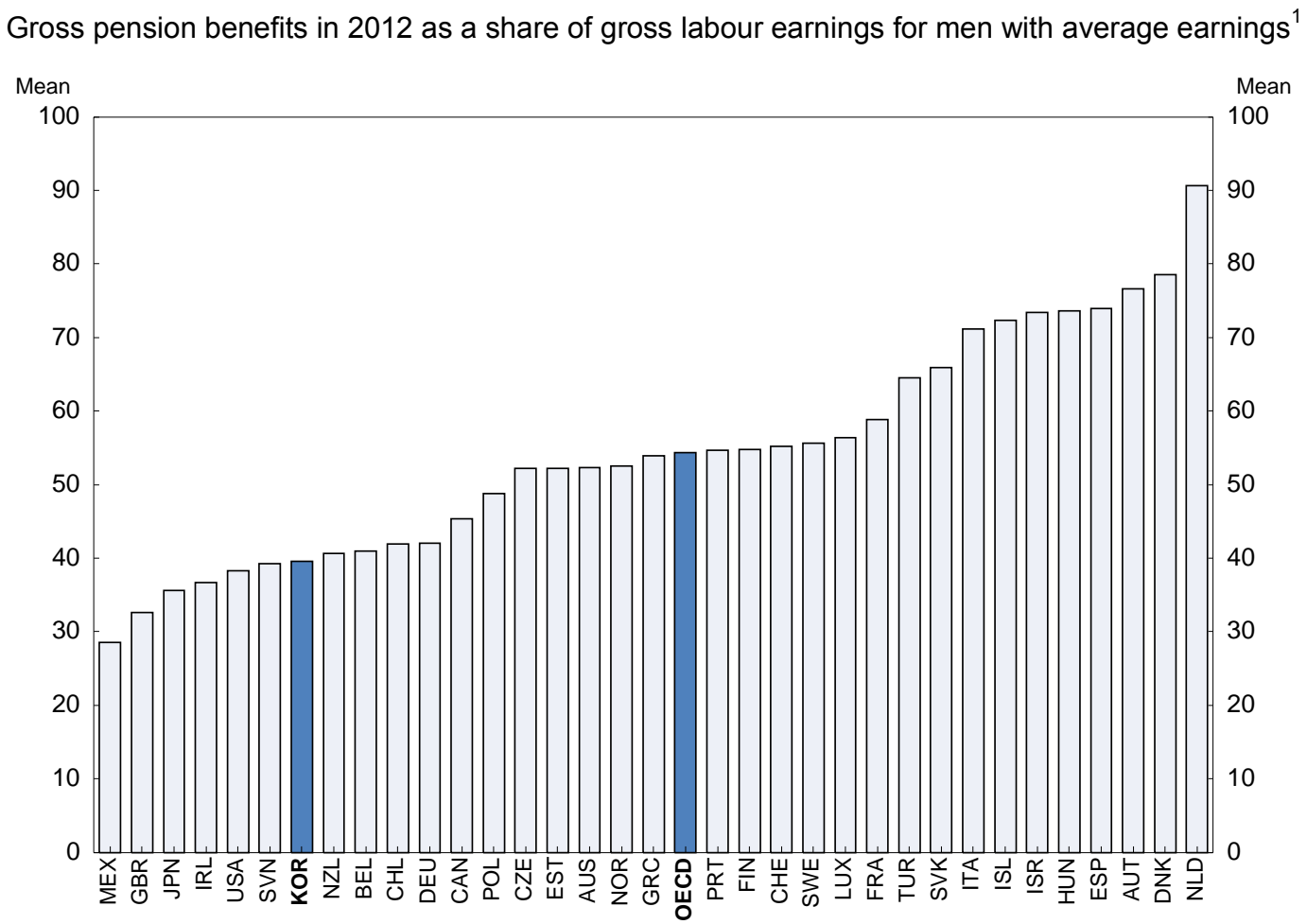

1. For mandatory pension schemes, public and private.

Source: OECD (2013a).

Reaching the $70 \%$ target through pension savings will likely require larger benefits from the NPS based on a three-pronged approach. First, the share of the working-age population contributing to the NPS should be increased from its current level of $43 \%$. Second, the average contribution period should be lengthened to provide higher pension benefits. Third, the replacement rate should be maintained around $50 \%$. Of course, such a higher replacement rate would require more revenue. If it were raised through contributions, the rate would have to rise to $16.7 \%$ to prevent a deficit in the NPS through 2083.

\section{Encouraging private-sector saving for retirement}

A financially sustainable and more generous NPS should be supplemented by greater private savings. It is thus important to accelerate the introduction of company pensions; at the current rate, it would take until 2019 to cover just one-half of all employees. It is important therefore to accelerate the shift away from the retirement allowance, given its weaknesses discussed above, and toward company pensions. In 2012, the government limited the payment of the retirement allowance before the worker leaves the company (including for retirement) to specific purposes. The government has recently reduced the favourable personal income tax preferences that allow the retirement allowance to be taxed over a number of years at a low rate. It is important to assess the effectiveness of this measure in promoting the adoption of company pensions. Another key aspect of the 2012 reforms was to require new firms to set up a company pension, based on preliminary consultations with employee representatives, without requiring a formal agreement, which has blocked the introduction of company pensions in some existing firms.

It is essential to expand the third pillar - Individual Pension Accounts, in part by increasing the penalties for early withdrawal of funds from the accounts to make them a more secure source of retirement 
income. In addition, more favourable treatment should be provided for existing contracts. Given that tangible assets, primarily real estate, accounted for $75 \%$ of total household assets in Korea in 2012, reverse mortgages - in which elderly homeowners take out loans that provide a monthly payment using their property as collateral - are an attractive option to deal with elderly poverty. The loans are only repaid when the contract expires or the homeowner dies. Reverse mortgages were introduced in 2007 for persons over the age of 60 who have one house and have paid off their mortgages. By the end of 2013, 17595 had been extended through a public financial institution. Private financial institution's participation is limited due to the risk related to housing prices and less favourable tax treatment in the past (Choi, 2013). The participation of private financial institutions should be encouraged.

\section{Household debt: implications for social cohesion}

Household debt has become a major policy concern in Korea. By the end of 2007, it had reached $146 \%$ of household disposable income, matching that in the United States. While the household debt ratio in many countries fell in the wake of the 2008 financial crisis, it continued to rise in Korea, reaching 164\% of disposable income by the end of 2012, well above the OECD average of 133\% (Figure 13). As debt rises, the household sector becomes increasingly sensitive to changes in income and interest rates, thus amplifying the impact of such shocks (Debelle, 2004). Higher debt also forces households to modify their consumption and investment, thus increasing the risk of a significant economic downturn (OECD, 2012a). The collapse of Korea's credit card bubble in 2003 illustrates the impact of household debt on economic growth. High levels of household debt, which are often linked to housing price bubbles, can also threaten financial-sector stability.

Addressing the household debt problem is also critical for social cohesion in Korea. The run-up in debt has made financial institutions increasingly reluctant to lend to households, particularly those with low incomes and poor credit ratings, at the same time as the financial needs of such households have been rising due to weak income growth. In addition, many delinquent borrowers have lost access to financial markets. If as a result, these individuals are excluded from financial markets, they would lose opportunities to improve their economic condition, thereby widening inequality.

\section{The government's response to high and rising household debt}

In 2011, the government announced a plan to "induce the soft-landing of household debt" (FSC and FSS, 2011), warning that it threatened economic and financial stability. The objective is to gradually reduce the household debt ratio, while avoiding a sharp deleveraging. In addition to reducing the level, the plan aims to address the multiple dimensions of household debt, based on a two-track approach: i) enhancing the soundness of financial markets by containing the risk caused by high household debt; and ii) expanding support for people with low income and credit ratings, the group most vulnerable to the weak economic conditions following the 2008 crisis.

The authorities have also acted to reduce the risk associated with household debt, in particular by strengthening prudential measures on financial institutions. For example, a higher risk weight was applied to loans that have higher rates of default, such as those to persons with three or more loans. Leverage regulations were tightened by requiring banks to lower their loan-to-deposit ratio and similar measures were introduced for non-bank financial institutions, including credit card companies. Special emphasis has been placed on reducing the risks associated with mortgage lending, which accounts for half of household debt. Given the higher risk of floating-rate and "bullet repayment" loans, ${ }^{11}$ financial supervisors are

11. With a bullet repayment loan, the borrower pays only interest during the term of the loan and pays off all of the principal when the loan reaches maturity, typically at three to five years. For more information on government measures to reduce the risk of household debt, see Jones and Kim (2014). 
requiring lenders to raise the share of fixed-rate and instalment payment mortgages. With housing prices falling gradually in real terms since 2008, the government has reversed some of the measures, such as the hike in capital gains taxes, which were implemented in the mid-2000s to stabilise housing prices. The sluggish housing market is reversing the expectations that real estate prices will always rise, opening the door to structural changes in the housing market, including the traditional chonsei system. ${ }^{12}$

Figure 13. An international comparison of household debt

As a per cent of net household disposable income in 2012
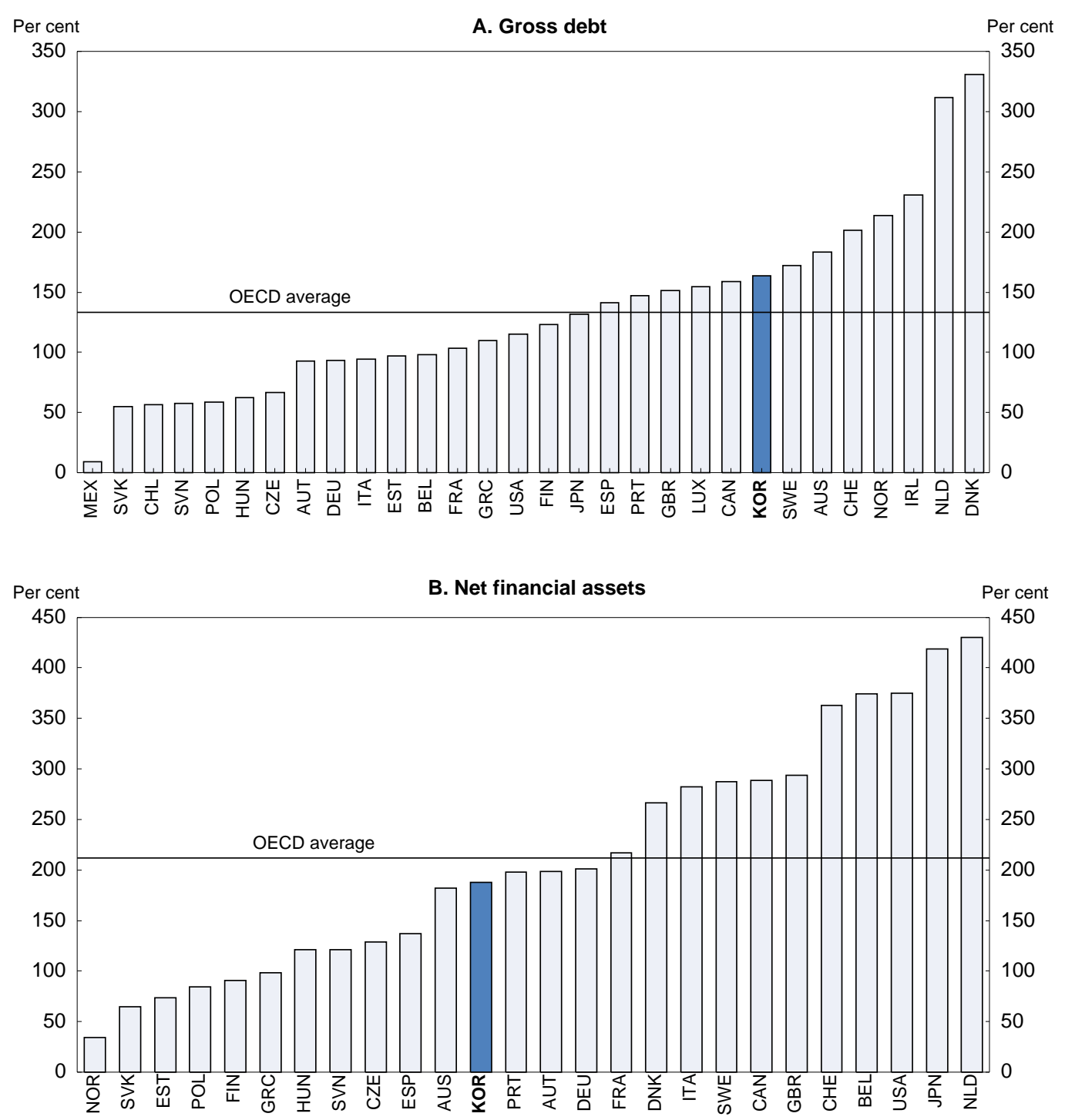

Source: OECD National Accounts at a Glance Database.

12. Under this system, a tenant deposits a lump sum for two years, instead of paying monthly rent, and the deposit - minus the interest earned by the owner - is refunded at the end of the contract. In 2010, about $54 \%$ of households lived in owner-occupied housing, while about one quarter each lived in chonsei housing and rental housing. For more information, see Jones and Kim (2014). 
The social cohesion aspect of household debt is linked to Korea's underdeveloped social safety net. Low-income households suffering from spells of unemployment, high health care costs or other financial losses have to rely on loans for basic necessities. According to a 2012 Bank of Korea survey of indebted households, $25 \%$ borrow money to pay for living costs. Government measures to promote social cohesion in the face of such problems have focused on providing sufficient credit to households with low income and credit ratings at an affordable price and restoring the credit of delinquent borrowers who are excluded from the regular financial market.

\section{Providing credit to households with low income and credit ratings at an affordable price}

Due to the high risk of default and the lack of sufficient collateral, financial institutions limit their lending to people with low income and credit ratings. Indeed, the share of loans to individuals with low credit ratings fell from $29 \%$ in 2006 to $24 \%$ in 2009 and further to $18 \%$ in $2011-12$ (Figure 14). ${ }^{13}$

In addition, $80 \%$ of individuals with low credit ratings depend on non-bank financial institutions and consumer finance companies for their borrowing, while banks focus on medium and high credit-rating borrowers (Table 5). This stratification of lending raises borrowing costs for disadvantaged borrowers, as the annualised interest rate on household loans charged by banks ranges from $5 \%$ to $14 \%$, well below the $25 \%$ to $40 \%$ of mutual saving banks, which are major players in lending to households (Table 6). The highest rates are charged by consumer finance companies. A 2013 government survey found that unregistered companies charge 53\% for household loans on average, and over $100 \%$ for around one-fifth of borrowers (FSS, 2013). ${ }^{14}$ Such rates far exceed the interest rate ceiling on loans to individuals and small enterprises, which was lowered from $49 \%$ to $44 \%$ in 2010 , to $39 \%$ in 2011 and further to $34.9 \%$ in 2014 , raising doubts as to whether this regulation actually helps disadvantaged borrowers. The survey also found that $44 \%$ of those with loans from consumer finance companies, including unregistered institutions, borrowed to pay for living costs.

Table 5. The share of household lending by type of financial institution varies based on credit ratings

In per cent ${ }^{1}$

\begin{tabular}{lcccc}
\hline & \multicolumn{2}{c}{$\begin{array}{c}\text { Medium and high-rated } \\
\text { borrowers }\end{array}$} & \multicolumn{2}{c}{ Poorly-rated borrowers } \\
\cline { 2 - 5 } Lender & 2010 & 2012 & 2010 & 2012 \\
\hline Banks & 50.0 & 46.3 & 20.0 & 18.1 \\
Non-bank financial institutions & 49.0 & 52.0 & 65.4 & 61.6 \\
Consumer finance companies & 1.0 & 1.7 & 14.6 & 20.2 \\
\hline
\end{tabular}

1. Covers non-secured lending to each credit-rating category as a share of total non-secured lending.

2. Borrowers ranked 1 to 6 on the ten-point scale used by Korean credit-rating agencies.

3. Borrowers ranked 7 to 10 on the ten-point scale used by Korean credit-rating agencies.

Source: Bank of Korea (2013).

13. Korean credit rating agencies classify people into ten grades, with 10 as the lowest. In Nam's study, a grade between 7 and 10 was classified as low. According to the Korea Credit Bureau, a credit-rating agency specialised in personal credit and whose shareholders are 18 major financial institutions, 41 million people had credit ratings at the end of June 2013. Of them, 6 million (14\%) had grades of 7 to 10 . The number with credit ratings exceeds the 38.5 million Koreans aged 19 and over in 2011, reflecting the inclusion of some youth and some people who have passed away, given lags in updating the database.

14. All consumer finance companies must register with the local government. Those that do not are operating illegally. 
Figure 14. The share of loans to individuals with low credit ratings is falling

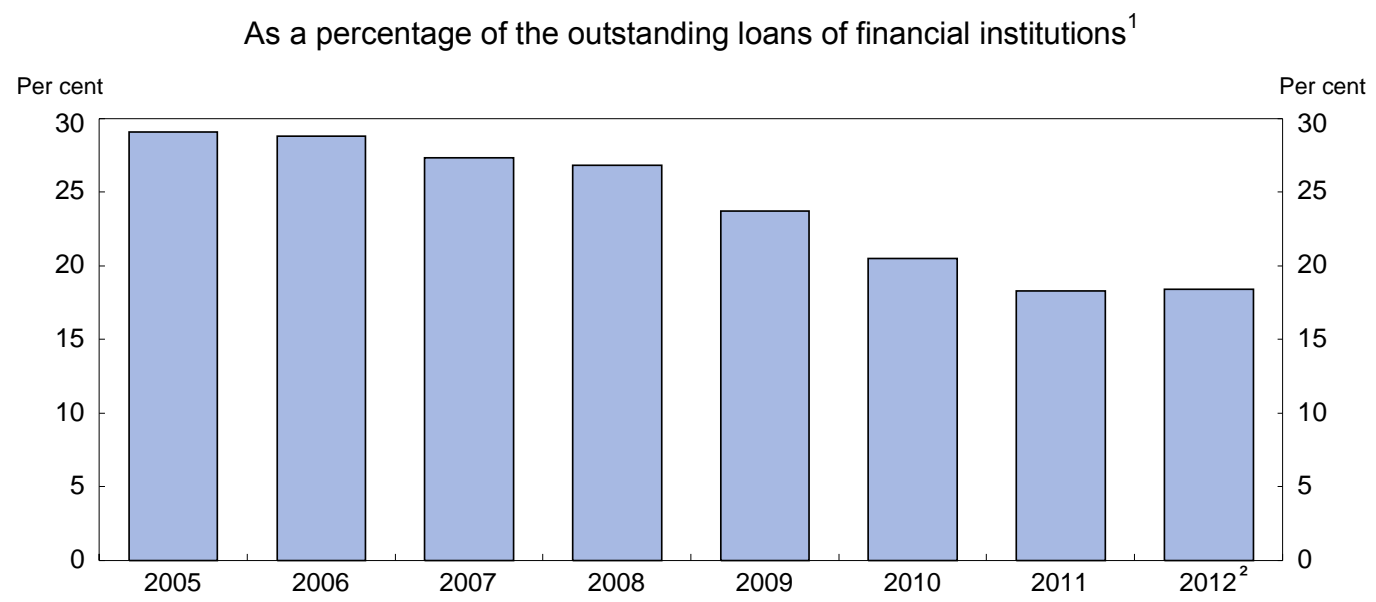

1. Defined as a credit rating of between 7 and 10 according to the Korea Credit Bureau. About 6 million persons $(14 \%$ of those with credit ratings) fell into that category as of June 2013.

2. October 2012.

Source: Nam (2013).

High interest rates increase the probability that borrowers with low credit ratings will default, creating a vicious circle that further reduces lending to such people and pushes up the interest rate. If a high interest rate is charged, only borrowers whose probability of default is high will agree to the loan, increasing the risk of default. To break this vicious circle, the government has introduced a number of programmes to provide loans to disadvantaged borrowers at preferential rates (Table 7).

Table 6. Interest rates on loans to households vary widely by type of lender

\begin{tabular}{lcc}
\hline Lender & Credit rating of main borrowers $^{1}$ & Interest rate $(\%)^{(\%-14}$ \\
\hline Banks & $1-3$ & $10-25$ \\
Mutual co-operation financial institutions & $2-6$ & $20-35$ \\
Financial institutions specialised in lending & $4-7$ & $25-40$ \\
Mutual saving banks & $5-9$ & $35-44$ \\
Consumer finance companies & $7-10$ & \\
\hline
\end{tabular}

1. Based on the ten-point scale used by Korean credit-rating agencies.

Source: FSC (2011).

\section{Restoring the credit of people who are already delinquent}

Assisting households currently excluded from the regular financial market due to their failure to service their debts is another challenge to social cohesion. Information on delinquent borrowers is reported by the financial institution concerned to the Korea Federation of Banks and shared among financial institutions, making it nearly impossible for delinquent borrowers to receive loans from regular financial institutions. Therefore, they need to turn to the unregistered market where borrowers must pay extremely high interest rates, as noted above. At such high interest rates, it is nearly impossible to escape their debt and many lives are ruined by predatory lenders. 
Table 7. Preferential loans to people with low income and poor credit ratings

\begin{tabular}{|l|l|l|c|c|}
\hline Programme & Channel & Financing & $\begin{array}{l}\text { Rating to } \\
\text { be eligible }\end{array}$ & $\begin{array}{l}\text { Interest } \\
\text { rate }\end{array}$ \\
\hline $\begin{array}{l}\text { Miso Finance } \\
(2008)\end{array}$ & $\begin{array}{l}\text { Branches of Miso } \\
\text { Finance }\end{array}$ & $\begin{array}{l}\text { Dormant savings accounts } \\
\text { Financial institutions and large companies }\end{array}$ & $7-10$ & $2-4.5 \%$ \\
\hline $\begin{array}{l}\text { Sunshine } \\
\text { Loans } \\
(2010)\end{array}$ & $\begin{array}{l}\text { Mutual saving banks } \\
\text { Mutual credit } \\
\text { institutions }\end{array}$ & $\begin{array}{l}\text { Financial institutions' own resources, with } \\
\text { publicly-funded credit guarantees }\end{array}$ & $6-10$ & $11-14 \%$ \\
\hline $\begin{array}{l}\text { New Hope } \\
\text { Seed Loans }\end{array}$ & Banks & Banks' own resources & $5-10$ & $6-14 \%$ \\
\hline $\begin{array}{l}\text { Switch-over } \\
\text { Dream Loan } \\
(2008)\end{array}$ & Banks & $\begin{array}{l}\text { Financial institutions own resources with } \\
\text { credit guarantees from the National } \\
\text { Happiness Fund }\end{array}$ & $6-10$ & Around $10 \%$ \\
\hline
\end{tabular}

1. Based on the Korean credit rating system where 1 is the best and 10 is the worst.

2. This programme restructures existing loans with interest rates above $20 \%$.

Source: FSC (2011) and FSC (2012).

To promote the restructuring of delinquent debt, the government has supplemented the court-based procedures with out-of-court workouts. Under court-based procedures, delinquent borrowers can be absolved of their debt through the Individual Rehabilitation Programme, which requires them to pay the restructured debt for five years. Alternatively, they can file for bankruptcy and let the court settle the debt. In the wake of the collapse of the credit card bubble, the Credit Counselling and Recovery Service has arranged individual workouts based on agreements with financial institutions to extend maturity and lower interest rates in order to reduce the burden on debtors. As financial difficulties intensified after the 2008 crisis, the government created the pre-workout programme, which provides individual workouts to borrowers who have failed to service their debt for between 30 and 90 days to prevent them from falling into long-term delinquency. However, in principle, the individual workouts did not allow the reduction of principal in order to prevent debtors' moral hazard (FSC, 2012).

However, the "National Happiness Fund", introduced in March 2013, allows restructuring to reduce principal and interest by up to $70 \%$, depending on the debtor's situation, raising concerns about moral hazard. Individuals who had borrowed less than 100 million KRW (around \$96 thousand) and were overdue by six months or longer as of February 2013 are eligible for this programme. Financial institutions that signed agreements with the Fund for credit recovery assistance are obliged to sell overdue loans to the Fund if their delinquent borrowers apply for debt restructuring. By October 2013, 4214 institutions had signed such agreements.

\section{The results of policies to address the social dimensions of household debt}

The number of delinquent borrowers, which peaked at 3.7 million in 2003, declined to 1.1 million in December 2013 (Figure 15), thanks in large part to the government programmes discussed above. Since $2008,12.7$ trillion KRW (1.0\% of 2012 GDP) has been provided to assist nearly 1.4 million people through the four major preferential loan programmes (Table 7). In addition, nearly one million delinquent borrowers have been assisted by the restructuring of their debt through out-of-court procedures (individual workouts, pre-workouts and the National Happiness Fund). The Fund alone accepted 214 thousand applicants during the May-October 2013 application period, resulting in a restructuring of 20.9 trillion KRW of debt. ${ }^{15}$ Still, about $5 \%$ of borrowing households remain delinquent, making it necessary to keep

15. Following the end of the six-month application period, the National Happiness Fund purchases loans from enlisted institutions and then conducts restructuring with the consent of borrowers who meet the same criteria as applied during the application period. For more information, see Jones and Kim (2014). 
up government efforts in this regard. The Three-year Plan for Economic Innovation, announced in February 2014, set a target of reducing the ratio of household debt to disposable income by 5 percentage points by 2017 through enhanced financial supervision and regulation (2014 OECD Economic Survey of Korea).

Figure 15. The number of borrowers listed as delinquent

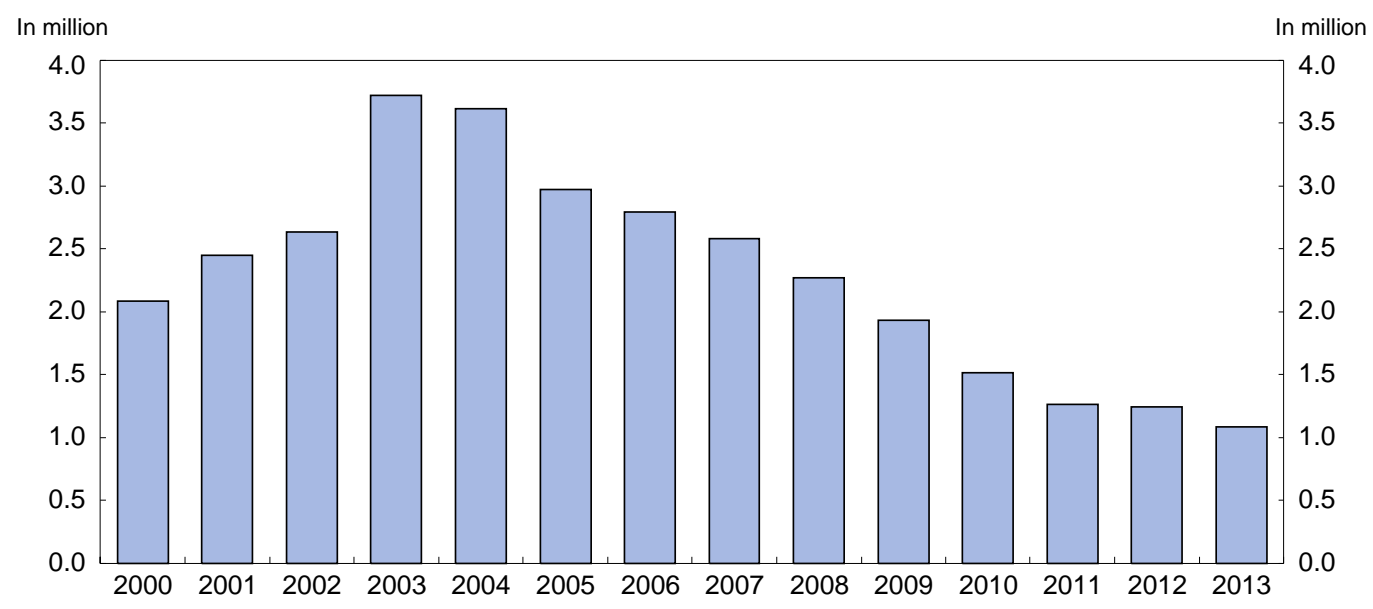

Source: Financial Supervisory Service.

One concern is the rise in the delinquency ratio of three of the preferential loan programmes (Miso Finance, Sunshine Loans and the Switch-over Dream Loan) to between $7.5 \%$ and $10 \%$, even though they carry low interest rates. These programmes should be redesigned to enhance their sustainability and reduce moral hazard. In the case of the New Hope Seed Loan programme, which is run by banks using their own resources, the delinquency ratio is much lower at less than $4 \%$. The preferential loans should not be regarded as free money and should be limited to those who have the ability and intention to service their debt. For debtors unable to service preferential loans, social welfare programmes would be more effective, and would prevent a further run-up in debt.

The debt restructuring programmes for delinquent borrowers can also create moral hazard problems. In particular, the large-scale write-off of existing debt through the National Happiness Fund may generate expectations that the government will intervene with such policies again in the future. It is important that the authorities maintain their pledge not to repeat such write-offs. At the same time, consumer financial education should be enhanced to help households carefully examine whether they can service their debt and to seek alternative solutions, such as social welfare assistance. Given that many low-income persons have limited financial knowledge, programmes run by the government or non-profit organisations are necessary (OECD, 2012c). While debtors are responsible for servicing their debt, financial institutions have the responsibility to avoid unsound lending. Lenders should make loans on the basis of careful credit evaluation as they also bear responsibility when debtors default.

The long-run goal should be to reduce the government's role and develop a market-based system to provide credit to households with low income and credit ratings. This calls for financial institutions to gain experience in such lending to enhance their capacity to evaluate credit risk. The role of small non-bank financial institutions, such as mutual saving banks and mutual credit institutions, in lending to creditworthy individuals with low income and credit ratings could be encouraged, given that banks have little interest. This would reduce the role of finance companies, which tend to charge predatory interest rates. 


\section{Box 1. Summary of recommendations to promote social cohesion in Korea}

\section{Labour market reforms}

- Break down dualism by reducing effective employment protection for regular workers, by expanding the coverage of non-regular workers through the social safety net and by increasing their access to vocational training.

- Extend the time limit on fixed-term contracts.

- Boost employment, particularly for women, youth and the elderly by breaking down dualism, reducing labour market mismatches, especially for youth through improved vocational education and training, and by extending older workers' careers in firms.

Increase the effectiveness of social welfare programmes in reducing income inequality and poverty

- Expand the Basic Livelihood Security Programme by further easing eligibility criteria and enforcing work requirements.

- Make the EITC more effective in reducing poverty by extending its coverage to more self-employed, as transparency about their income increases, and extending the phase-out range to avoid reducing work incentives.

Enhance the contribution of education to social cohesion

- Raise the quality of childcare to ensure that households at all income levels have access to high-quality preschool education.

- Reduce reliance on private tutoring by developing the "school record system" for university admission, raising the quality and diversity of secondary schools and reducing the over-emphasis on higher education by improving vocational education.

\section{Reduce poverty among the elderly}

Immediate priorities to address poverty, while ensuring the sustainability and effectiveness of the NPS

- Target the Basic Old-Age Pension on the lowest-income elderly to ensure that all escape from absolute poverty $(40 \%$ of national median income).

- Use the Basic Livelihood Security Programme to top up the income of the elderly in relatively poverty $(50 \%$ of the national median income) by further relaxing eligibility requirements.

- Make the NPS more effective in reducing elderly poverty by expanding its coverage, focusing on improved compliance among non-regular and self-employed workers, lengthening average contribution periods and maintaining the NPS replacement at around 50\%, keeping it close to the OECD average.

- Begin as soon as possible to raise the NPS contribution rate to a level sufficient to ensure its long-run sustainability.

Encouraging private-sector saving for retirement

- Accelerate the introduction of company pensions.

- Make Individual Pension Accounts a more important source of retirement income by measures to discourage their premature termination and develop the market for reverse mortgages.

\section{Address the social implications of household debt}

- $\quad$ Promote the development of lending by local non-bank financial institutions to disadvantaged households that are credit-worthy.

- Ensure the long-run viability of preferential loan programmes by granting loans only to those who are capable and willing to service their loans. For others, replace preferential loans with an expanded social safety net.

- Avoid additional programmes offering large write-offs of principal and interest so as to avoid moral hazard.

- Discourage excessive lending to households by financial institutions through appropriate prudential supervision and promote financial education for households to prevent over-borrowing. 


\section{BIBLIOGRAPHY}

Antolin, P. (2009), "Private Pensions and the Financial Crisis: How to Ensure Adequate Retirement Income from DC Pension Plans", Financial Market Trends, Vol. 2009/2, OECD Publishing, Paris, http://dx.doi.org/10.1787/fmt-v2009-art22-en.

Bank of Korea (2013), Financial Stability Report, April, Seoul.

Chang, S. (2009), "A Cultural and Philosophical Perspective on Korea's Education Reform: A Critical Way to Maintain Korea's Economic Momentum", Academic Paper Series on Korea, Korea Economic Institute, Washington, DC.

Choi, S (2013), "Trends in the Domestic Housing Pension Market and Implications", HANA Happiness Guide 2013, No. 02, HANA Institute of Finance (in Korean).

Chung, K. (2010), "Old-Age Income Security System in Korea and Future Policy Issues", KIHASA Working Papers, 2010-03, Korea Institute for Health and Social Affairs, Seoul.

Debelle, G. (2004), "Macroeconomic Implications of Rising Household Debt", BIS Working Papers, No. 153, Basel.

Financial Services Commission (2011), Current Situation of Financial Support Programmes for People with Low Income and Credit Ratings and the Plan for the Future, Seoul (in Korean).

Financial Services Commission (2012), The Outcome of Financial Support Programmes for the People with Low Income and Credit Ratings and the Plan for the Future, Seoul (in Korean).

Financial Services Commission and Financial Supervisory Service (2011), Comprehensive Policy Measures to Induce a Soft-landing of Household Debt, Seoul (in Korean).

Financial Supervisory Service (2013), Survey on Users of Consumer Finance Companies, Seoul (in Korean).

Jones, R. (2008), "Reforming the Tax System in Korea to Promote Economic Growth and Cope with Rapid Population Ageing", OECD Economics Department Working Papers, No. 671, OECD Publishing, Paris, $h t t p: / / d x$.doi.org/10.1787/226518762318.

Jones, R. (2013), "Education Reform in Korea", OECD Economics Department Working Papers, No. 1067, OECD Publishing, Paris, http://dx.doi.org/10.1787/5k43nxs1t9vh-en.

Jones, R. and M. Kim (2014), "The Multiple Dimensions of Household Debt in Korea and Policy Implications", OECD Economics Department Working Papers (forthcoming), OECD Publishing, Paris.

Jones, R. and S. Urasawa (2014), "Reducing the High Rate of Poverty Among the Elderly in Korea", OECD Economics Department Working Papers (forthcoming), OECD Publishing, Paris. 
Kahn, L. (2010), "Labor Market Policy: A Comparative View on the Costs and Benefits of Labor Market Flexibility", CESIFO Working Papers, No. 3140.

Kim, H. and D. Lee (2013), “A Study on Employment Stabilization After Non-Regular Workers' Transition to Regular Status”, Korea Labor Review, No. 47, Korea Labour Foundation, Seoul.

Kim, J. (2011), "Women's Career Disconnect and Re-entry into the Labor Market", Labor Issues in Korea 2010, edited by K. Bae, Korea Labor Institute, Seoul.

Kim, J. and H. Moon (2011), "Pension Systems for Public Sector Employees in the Republic of Korea", Institute of Economic Research, Hitotsubashi University, PIE-CIS Discussion Papers, No. 499.

Kim, S. (2013), "Pension Reform Options in Korea”, IMF International Conference, Tokyo, January.

Koh, Y. (2011), "Social Safety Net in Korea: From Welfare to Workfare", Korea Development Institute, mimeo, Seoul.

Koh, Y., S. Kim, C. Kim, Y. Lee, J. Kim, S. Lee and Y. Kim (2010), "Social Policy", in The Korean Economy: Six Decades of Growth and Development, edited by I. SaKong and Y. Koh, Korea Development Institute, Seoul.

Lee, Y. (2012), "A Study on Old-Age Income Security Policy Measures to Cope with Population Aging and Income Polarization", Research Papers, National Pension Research Institute, Seoul.

Ministry of Education (2011), Analysis of the Results of the 2010 Survey on Private Education Costs, Seoul (in Korean).

Ministry of Employment and Labour (2012), Recent Labour Market Trends, September.

Ministry of Health and Welfare (2013), The 2012 Basic Old-Age Pension from a Statistical Perspective, Seoul (in Korean).

Nam, J. (2013), "Current Situation of Financial System for the People with Low Income and Credit Ratings and Measures to Facilitate it", Presented at the Conference jointly held by the Korea Institute of Finance and the Korea Economic Association, Seoul (in Korean).

National Pension Research Institute (2013), A Summary of the 2013 Actuarial Projection Result, Seoul.

National Pension Service (2012a), National Pension Statistical Yearbook, Seoul.

National Pension Service (2012b), Working Together for a Better Tomorrow, Seoul.

OECD (2011), Pensions at a Glance, OECD Publishing, Paris, http://dx.doi.org/10.1787/pension_glance2011-en.

OECD (2012a), "Debt and Macroeconomic Stability", OECD Economics Department Policy Notes, No. 16, OECD Publishing, Paris.

OECD (2012b), OECD Economic Survey of Korea, OECD Publishing, Paris, http://dx.doi.org/10.1787/eco_surveys-kor-2012-en. 
OECD (2012c), OECD/INFE High-level Principles on National Strategies for Financial Education, OECD Publishing, Paris.

OECD (2013a), Pensions at a Glance, OECD Publishing, Paris, http://dx.doi.org/10.1787/pension_glance2013-en.

OECD (2013b), PISA 2012 Results: What Makes a School Successful (Volume IV), OECD Publishing, Paris, http://dx.doi.org/10.1787/9789264201156-en.

OECD (2013c), Strengthening Social Cohesion in Korea, OECD Publishing, Paris, http://dx.doi.org/10.1787/9789264188945-en.

OECD (2013d), The Survey of Adult Skills, OECD Publishing, Paris, http://dx.doi.org/10.1787/9789264204027-en.

OECD (2014a), OECD Economic Survey of Korea, OECD Publishing, Paris.

OECD (2014b), OECD Skills Strategy Diagnostic Report: Korea (forthcoming), OECD Publishing, Paris.

Seok, S., H. Kwon, H. Song, E. Lee, J. Oh, H. Shin and G. Kim (2012), “Middle- and Old-Aged Koreans' Preparation Realities for and Expectations about their Old Age", Research Papers, National Pension Research Institute, Seoul.

Statistics Korea (2013), 2013 Statistics on Career-Break Women, Daejeon (in Korean).

Yamaguchi, K. and Y. Youm (2012), "The Determinants of Low Marital Fertility in Korea: A Comparison with Japan”, RIETI Discussion Paper Series, 12-E-013, Tokyo.

Yoon, H. (2013), "Korea: Balancing Economic Growth and Social Protection for Older Adults", The Gerontologist, Vol. 53, No. 3.

Yun, S. (2013), "Current Status and Condition of Elderly Poverty and Income Distribution, and Direction of Income Support", Health and Welfare Forum, KIHASA, Seoul. 
ECO/WKP(2014)49

\section{WORKING PAPERS}

The full series of Economics Department Working Papers can be consulted at www.oecd.org/eco/workingpapers

1152. Fostering a creative economy to drive Korean growth

(July 2014) by Randall S. Jones

1151. Economic uncertainties and their impact on activity in Greece compared with Ireland and Portugal

(July 2014) by Jan-David Schneider and Claude Giorno

1150. Workplace stress in the United States: issues and policies

(July 2014) by Michael Darden

1149. Taxing the rent of non-renewable resource sectors: a theoretical note

(July 2014) by Julien Daubanes and Saraly Andrade de Sá

1148. Health, work and working conditions: a review of the European economic literature

(July 2014) by Thomas Barnay

1147 Making the best of new energy resources in the United States

(July 2014) by Douglas Sutherland

1146. Improving well-being in the United States

(July 2014) by Aida Caldera Sánchez, Patrick Lenain and Sarah Fléche

1145. Deconstructing Canada's housing markets: finance, affordability and urban sprawl

(July 2014) by Calista Cheung

Restructurer les marchés canadiens du logement: financements, accessibilité financière et étalement urbain

(Juillet 2014) par Calista Cheung

1144. Women's role in the Swiss economy

(July 2014) by Richard Dutu

Le rôle des femmes dans l'économie suisse

(Juillet 2014) par Richard Dutu

1143. Overcoming skills shortages in Canada

(July 2014) by David Carey

Combler les pénuries de compétences au Canada

(Juillet 2014) par David Carey

1142. Trade patterns in the 2060 world economy

(July 2014) by Jean Chateau, Lionel Fontagné, Jean Fouré, Åsa Johansson and Eduardo Olaberria

1141. The Demand for Skills 1995-2008: A global chain perspective

(July 2014) by Bart Los, Marcel P. Timmer and Gaaitzen J. De Vries

1140. International migration: The relationship with economic and policy factors in the home and destination country

(July 2014) by Ben Westmore 
1139. Gross earning inequalities in OECD countries and major non-member economies: determinants and future scenarios

(July 2014) by Henrik Braconier and Jenifer Valenzuela Ruiz

1136. Long-term patterns of trade and specialisation

(July 2014) by Asa Johansson and Eduardo Olaberria

1135. Consequences of climate change damages for economic growth - a dynamic quantitative assessment

(July 2014) by Rob Dellink, Elisa Lanzi, Jean Chateau, Francesco Bosello, Ramiro Parrado and Kelly de Bruin

1134. Comparing the robustness of PAYG pension schemes

(July 2014) by Falilou Fall

1133. Overcoming vulnerabilities of pension systems

(July 2014) by Falilou Fall and Debbie Bloch

1132. Overcoming vulnerabilities of health care systems

(July 2014) by Mauro Pisu

1131. Overcoming vulnerability of unemployment insurance schemes

(July 2014) by Jon Pareliussen

1130. Vulnerability of social institutions: Lessons from the recent crisis and historical episodes

(July 2014) by Falilou Fall, Mauro Pisu, Jon Pareliussen and Debbie Bloch

1129. An update of the OECD international trade equations

(June 2014) by Myriam Morin and Cyrille Schwellnus

1128. What explains the volume and composition of trade? Industrial evidence from a panel of countries

(June 2014) by Asa Johansson, Przemyslaw Kowalski, Eduardo Olaberria and Dario Pellegrino

1127. Do resources flow to patenting firms: cross-country evidence from firm level data

(June 2014) by Dan Andrews, Chiara Criscuolo and Carlo Menon

1126. Macroprudential policy tools in Norway: Strengthening financial system resilience

(June 2014) by Yosuke Jin, Patrick Lenain and Paul O’Brien

1125. Strengthening competition in Poland

(June 2014) by Balász Égert and Antoine Goujard

1124. Making the labour market work better in Poland

(June 2014) by Hervé Boulhol

1123. Enhancing competition and the business environment in Hungary

(June 2014) by Alvaro Pina 